NUREG/CR-3354 PNL-4761

\title{
Potentially Buoyant Releases at Boiling and Pressurized Water Reactors
}

Prepared by J. V. Ramsdell, D. W. Faletti, M. A. McLean, G. J. Laughlin

Pacific Northwest Laboratory .

Operated by

Battelle Memorial Institute

Prepared for

U.S. Nuclear Regulatory

Commission 
This report was prepared as an account of work sponsored by an agency of the United States Government. Neither the United States Government nor any agency thereof, or any of their employees, makes any warranty, expressed or implied, or assumes any legal liability of re. sponsibility for any third party's use, or the results of such use, of any information, apparatus, product or process disclosed in this report, or represents that its use by such third party would not infringe privately owned rights.

\section{Availability of Reference Materials Cited in NRC Publications}

Most documents cited in NRC publications will be available from one of the following sources:

1. The NRC Public Document Room, 1717 H Street, N.W. Washington, DC 20555

2. The NRC/GPO Sales Program, U.S. Nuclear Regulatory Commission, Washington, DC 20555

3. The National Technical Information Service, Springfield, VA 22161

Although the listing that follows represents the majority of documents cited in NRC publications, it is not intended to be exhaustive.

Referenced documents available for inspection and copying for a fee from the NRC Public Document Room include NRC correspondence and ir.ternal NRC memoranda; NRC Office of Inspection and Enforcement bulletins, circulars, information notices, inspection and investigation notices; Licensee Event Reports; vendor reports and correspondence; Commission papers; and applicant and licensee documents and correspondence.

The following documents in the NUREG series are available for purchase from the NRC/GPO Salex Program: formal NRC staff and contractor reports, NRC-sponsored conference proceedings, and NRC booklets and brochures. Also available are Regulatory Guides, NRC regulations in the Code of Federal Regulations, and Nuclear Regulatory Commission /ssuances.

Documents available from the National Technical Information Service include NUREG series reports and technical reports prepared by other federal agencies and reports prepared by the Atomic Energy Commission, forerunner agency to the Nuclear Regulatory Commission.

Documents available from public and special technical libraries include all open literature items, such as books, journal and periodical articles, and transactions. Federal Register notices, federal and state legislation, and congressional reports can usually be obtained from these libraries.

Documents such as theses, dissertations, foreign reports and translations, and non-NRC conference proceedings are available for purchase from the organization sponsoring the publication cited.

Single copies of NRC draft reports are available free upon written request to the Division of Technical Information and Document Control, U.S. Nuclear Regulatory Commission, Washington, DC 20555.

Copies of industry codes and standards used in a substantive manner in the NRC regulatory process are maintained at the NRC Library, 7920 Norfolk Avenue, Bethesda, Maryland, and are available there for reference use by the public. Codes and standards are usually copyrighted and may be purchased from the originating organization or, if they are American National Standards, from the American National Standards Institute, 1430 Broadway, New York, NY 10018. 
NUREG/CR-3354

PNL-4761

\section{Potentially Buoyant Releases at Boiling and Pressurized Water Reactors}

Manuscript Completed: July 1983

Date Published: October 1983

Prepared by

J. V. Ramsdell, D. W. Faletti, M. A. McLean,

G. J. Laughlin

Pacific Northwest Laboratory

Richland, WA 99352

Prepered for Division of Systems Integration Office of Nuclear Reactor Regulation U.S. Nuclear Regulatory Commission Washington, D.C. 20555

NRC FIN B2514 

Representative designs for boiling and pressurized light water reactors have been reviewed to identify potential sources for short-term buoyant plumes that might be associated with low probability events at nuclear power plants. Techniques for evaluating the consequences of the buoyant releases are described. The techniques are applied to the releases following the January 25, 1982, steam generator tube rupture at the R. F. Ginna Nuclear Power Plant. Finally, NRC guidance to licensees is discussed.

Potential sources for radioactive, buoyant plumes at boiling water reactors include main steam line breaks, and breaks in the high pressure core injection line and residual heat removal system. For pressurized water reactors, the potential sources of radioactive, buoyant plumes include steam generator tube ruptures followed by the opening of safety and dump valves, and breaks in the residual heat removal and letdown lines.

The effluent released in these events will range from superheated steam at $149^{\circ} \mathrm{C}$ to a steam water mixture at about $100^{\circ} \mathrm{C}$. Shortly following release the effluent will become supersaturated and may condense. Droplet nucleation is likely on any particulate material released with the steam, and the droplets are likely to fall out of the plume near the release point.

of the potential buoyant releases, the releases following a PWR stearn generator tube rupture are most amenable to evaluation in general terms, because they vent directly to the atmosphere. The flows are determined by the ratings of the valves and the dimensions of the vents. For the other potential releases, the flows are determined by the specific nature of the breaks in the lines. Maximum flows can be estimated by assuming complete breaks in the lines. However, there is no assurance that the breaks would be complete. Further, the path between one of these breaks and the atmosphere depends on the magnitude of the break. If a large break occurs, it is likely that the effluent will reach the atmosphere by breaching the side of the reactor building, steam tunnel or turbine building. Otherwise, the effluent would be released through the normal building ventilation system. 



\section{ACKNOWLEDGMENT}

The authors wish to take this opportunity to acknowledge the guidance provided by the NRC Technical Monitor, James Fairobent. His assistance has been greatly appreciated. 



\section{CONTENTS}

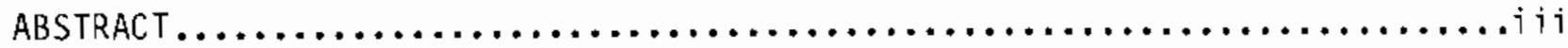

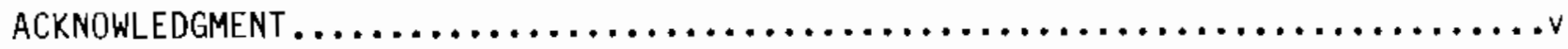

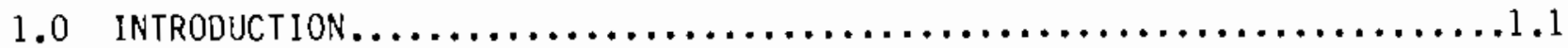

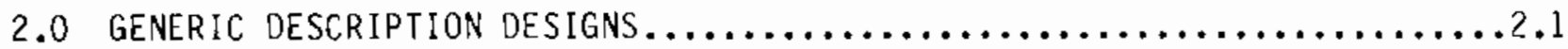

2.1 BOILING WATER REACTORS ............................

2.2 PRESSURIZED WATER REACTOR $\ldots \ldots \ldots \ldots \ldots \ldots \ldots \ldots \ldots \ldots \ldots \ldots \ldots \ldots \ldots \ldots$

3.0 ATMOSPHERIC BEHAVIOR OF POTENTIALLY BUOYANT RELEASES ..............

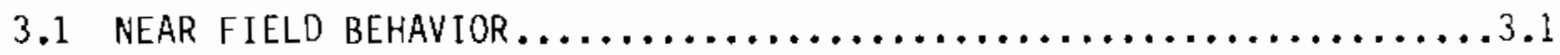

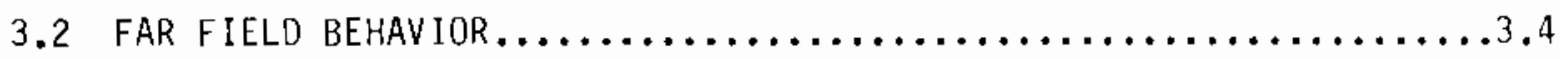

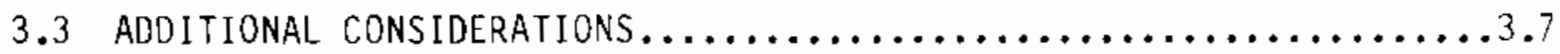

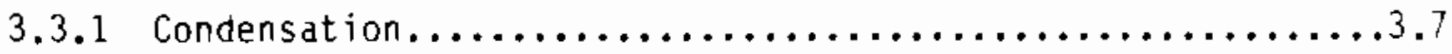

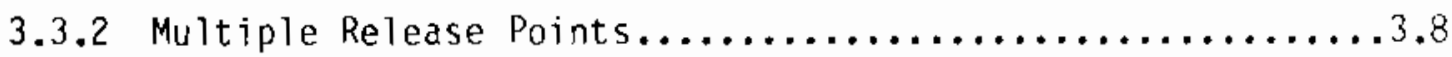

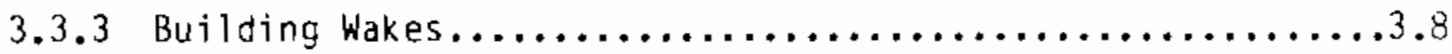

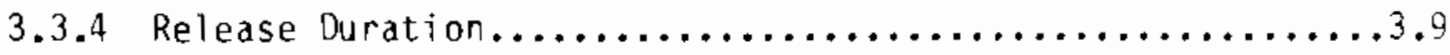

4.0 BOILING WATER REACTOR RELEASES .........................

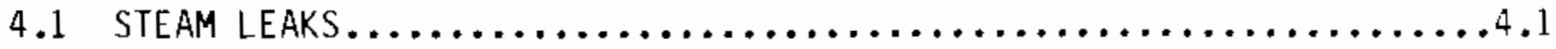

4.2 Superheate liquid Line Breaks....................... 10

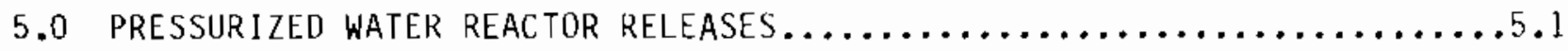

5.1 BABCOCK \& WILCOX REACTORS ........................ $\ldots .4$

5.2 WESTINGHOUSE REACTORS ..........................

5.3 COMBUStion ENGINEERING (CE) REACTORS..................

6.0 EVALUATION OF POTENTIAL RELEASES $\ldots \ldots \ldots \ldots \ldots \ldots \ldots \ldots \ldots \ldots \ldots \ldots \ldots .6 \ldots \ldots$

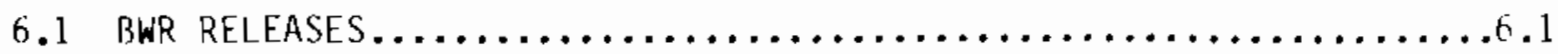

6.2 PWR RELEASES .................................. 
6.3 ATMOSPHERIC BEHAVIOR............................ 6.5

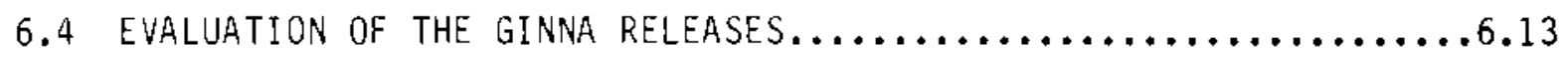

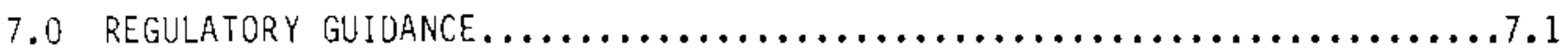

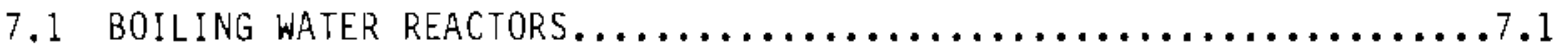

7.2 PRESSURIZED WATER REACTORS ......................

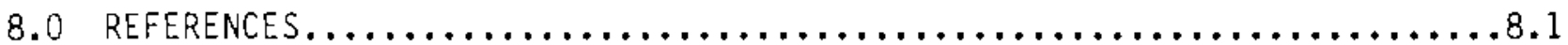




\section{FIGURES}

2.1 Simplified Flow Diagram of a Thermal Power Plant....................

2.2 Simplified Flow Diagram of a Boiling Water Reactor Power Plant.........2.1

2.3 Simplified Flow Diagram of a Pressurized-Water Reactor Power

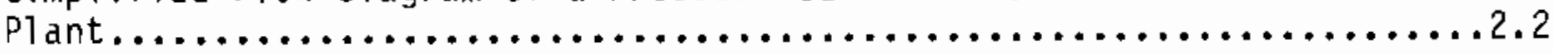

4.1 Schematic of a Main Steam Line Break Inside the Steam Tunnel..........4.2

4.2 Plan and Side View of Unit 3 Browns Ferry Nuclear Station...............

4.3 Side and Plan Views of Susquehanna Nuclear Station..................4.4

4.4 Simplified Plan View and Side View of Unit 2 Grand Gulf

Nuclear Station..............................................

4.5 Steam and Water Flows for a Main Steam Line Break at Browns

Ferry Nuclear Station...................................... 4

4.6 Schematic of Feedwater Line Break Between Heaters and

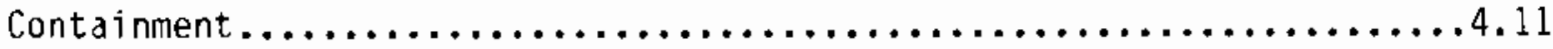

6.1 Plume Rise at $100 \mathrm{~m}$ as a Function of Buoyancy Parameter, Wind

Speed and Stability.............................................. 6

6.2 Plume Radius at $100 \mathrm{~m}$ as a Function of Buoyancy Source..............6.7

6.3 Final Plume Rise for F Stability........................... 8

6.4 Distance to Final Plume Rise for Stable Atmospheric Conditions........ 6.9

6.5 Decrease of Specific Humidity and Temperature in the Near Field

Plume from $100^{\circ} \mathrm{C}$ Steam Release in a $15^{\circ} \mathrm{C}$ Atmosphere...............6.10

6.6 Decrease in Specific Humidity in the Near Field Plume of a

$100^{\circ} \mathrm{C}$ Saturated Steam Release as a Function of Distance

from the Source..............................................

6.7 Same as Figure 6.6 Except for $149^{\circ} \mathrm{C}$ Superheated Steam Release.......6.12

6.8 Estimated Time Integrated, Normalized Ground-Level Air

Concentrations for Various Effective Release Height

Assumptions for Early Ginna Steam Releases......................6.15

6.9 Normalized Surface Deposition Under a Plume Center Line............6.16 



\section{TABLES}

4.1 Effluents From a Main Steam Line Break........................... 4.7

4.2 Release Points for Main Steam Line Breaks.........................

4.3 Approximate Main Steam Line Break Flow Splits at Susquehanna...........4.9

4.4 Other Steam Breaks at Susquehanna Nuclear Station...................10

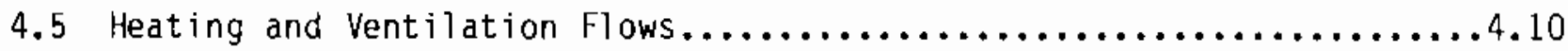

5.1 Steam Release Conditions for a Steam Generator Tube Rupture With and Without Loss of Offsite Power for a Babcock \& Wilcox Reactor.................................................. 5.2

5.2 Atmospheric Dump and Safety Relief Valve Setpoints and Rated

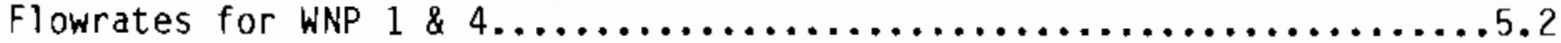

5.3 Atmospheric Dump and Safety Relief Valve Setpoints and Rated Flow Rates for Trajan........................................ 5

5.4 Steam Release Conditions for Steam Generator Tube Rupture With Loss of Offsite Power for Westinghouse Reactors................ 6

5.5 Atmospheric Dump and Safety Relief Valve Setpoints and Rated Flowrates for Palo Verde...................................... 7

5.6 Steam Release Conditions for a Combustion Engineering Reactor Steam Generator Tube Rupture with and Without Offsite Power........... 8

6.1 Typical Release Characteristics for Potentialiy Buoyant Plumes from Boiling water Reactors $\ldots \ldots \ldots \ldots \ldots \ldots \ldots \ldots \ldots \ldots \ldots \ldots .6 .2$

6.2 Typical Release Characteristics for Potentially Buoyant Plumes for Pressurized water Reactors........................... 6 



\subsection{INTRODUCTION}

A number of low probability events at nuclear power plants, which are less severe than loss-of-coolant-accidents, have the potential to result in shortterm buoyant releases of radioactive material. These events, including steam line ruptures in boiling water reactors (BWRs) and steam generator tube ruptures in pressurized water reactors (PWRs), are not expected to occur at each reactor, but they can be expected to occur occasionally within the nuclear power industry. This report identifies potential sources of short-term, buoyant plumes and evaluates the likely behavior of the plumes near the release points. It discusses the guidance provided in Regulatory Guide 1.5 (USNRC 1971) on plume behavior assumptions for use in evaluating the radiological consequences of a steam line break for BWRs, and it suggests possible guidance for use in evaluating the consequences of stearn generator tube ruptures in PWRs.

Potential sources of buoyant plumes were identified by examining safety analysis reports for representative designs for power reactors under construction or operating in the United States. General Electric, Babcock and Wilcox, Westinghouse and Combustion Engineering designs were included in the sample. Steam and hot water lines outside of containment that normally, or could potentially, contain contaminated steam or water were identified. The maximum release rates, thermodynamic states and the likely pathways from possible release points - i.e., steam 1 ine break, safety valves, etc. - to the free atmosphere were estimated for effluents from these lines. In some cases, the likely pathways could permit significant modification of the effluent prior to its final venting. These modifications could include reduction of the temperature and momentum of the effluent and condensation of steam. For those cases in which no modification is likely, the maximum potential release rates and thermodynamic states of postulated breaks or flows through valves were used to estimate plume behavior.

Simple models of plume behavior were used to evaluate the likelihood of condensation within the plume and plume rise. In these models, mixing between the plume and the atmosphere is assumed to be a function of distance from the vent. As the distance from the vent increases, atmospheric conditions become important.

For those releases with sufficient buoyancy to rise well above heights normally associated with reactor building complexes, diffusion estimates were made to a distance of $1 \mathrm{~km}$ using standard elevated source diffusion equations. The plumes were assumed to originate at an upwind virtual point source. The distance to the virtual point source was computed to give diffusion coefficient values appropriate to the radius of the plume at the final rise height.

The remainder of the report is organized as follows: Sections 2 and 3 provide background information on the steam cycles in nuclear power plants (both BWRs and PWRs) and on the atmospheric processes related to plume development, transport and diffusion. Section 4 discusses releases from BWRs, and Section 5 treats PWRs. In these two sections the likely release points are 
identified, the maximum release rates are estimated, the thermodynamic state of the effluents is estimated, and the potential pathways to the atmosphere are outlined. Section 6 evaluates the consequences of the postulated releases once they reach the atmosphere. Finally, Section 7 discusses guidance for evaluation of potentially buoyant releases. 


\subsection{GENERIC DESCRIPTION OESIGNS}

Thermal power plants produce most of this country's electricity. A source of heat is used to form steam which is passed through a turbine generator which converts thermal energy into electricity. The steam leaving the turbine is condensed and pumped back to the steam supply system. The heat removed from the steam in the condenser is transferred to a heat sink. This process is illustrated in Figure 2.1

Light water nuclear reactor power plants use the cycle shown in Figure 2.1. They differ from coal or oil fired plants in that the heat to form the steam is furnished by a nuclear reactor. Two types of light water reactor power plants are in use in the United States; the boiling water reactor (BWR) and the pressurized water reactor (PWR). Simplified flow diagrams are shown for each in Figures 2.2 and 2.3. Steam driven turbine-generators operating at

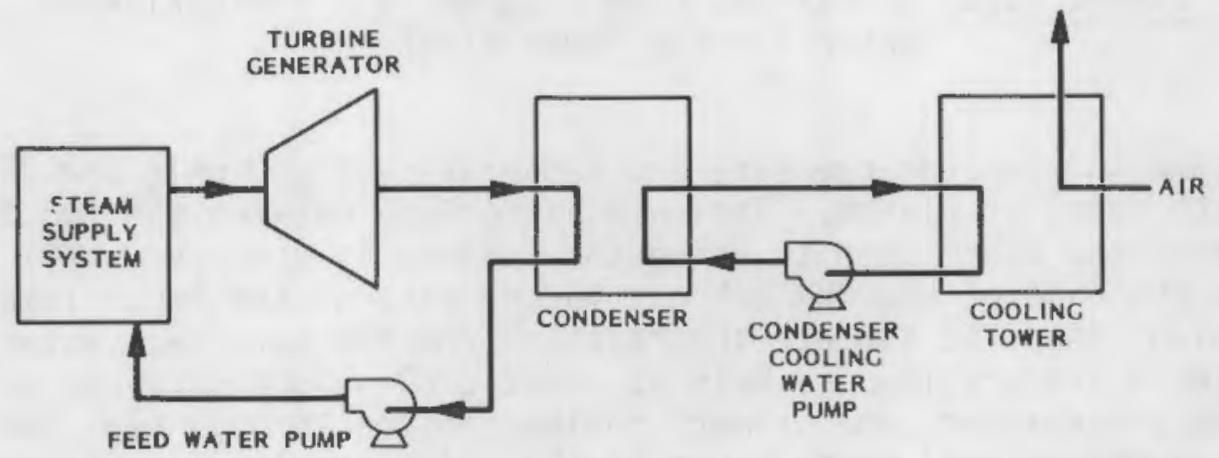

FIGURE 2.1. Simplified Flow Diagram of a Thermal Power Plant

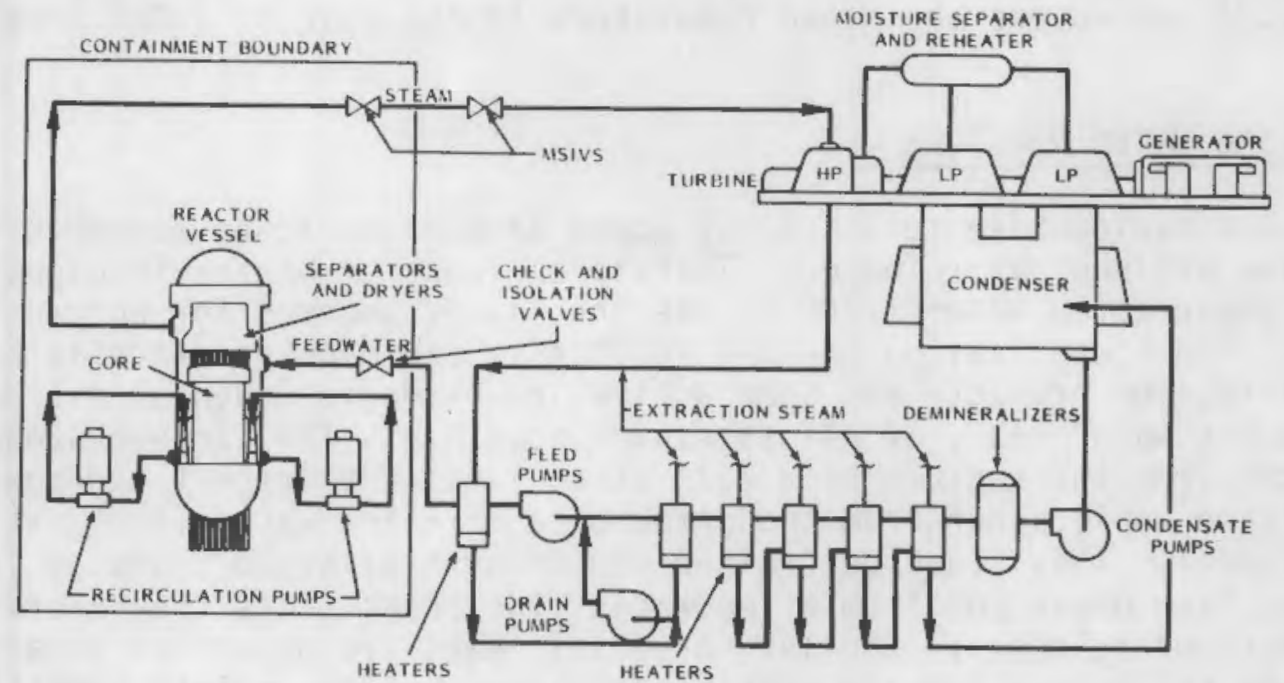

FIGURE 2.2. Simplified Flow Diagram of a Boiling Water Reactor Power Plant 


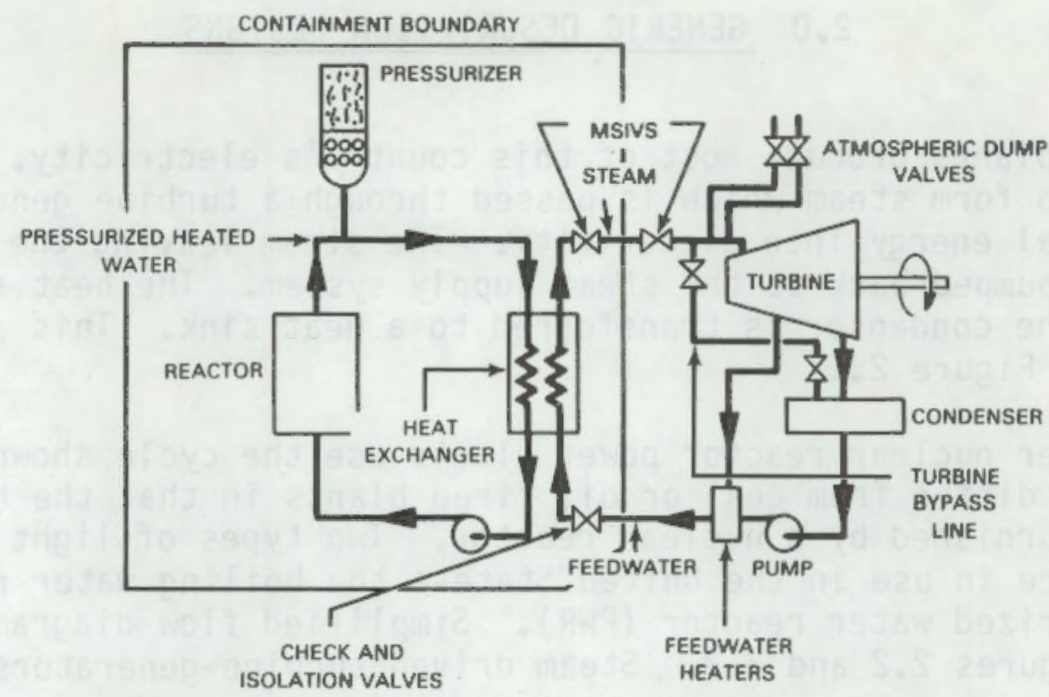

FIGURE 2.3. Simplified Flow Diagram of a PressurizedWater Reactor Power Plant

about the same inlet steam pressure and temperature $\left(1000 \mathrm{psig}\right.$ and $\left.282^{\circ} \mathrm{C}\right)$ are used for both types of plants. The main difference between the two types of plants is that the steam used to drive the turbine is produced within the reactor core in the case of the BWR but not in the case of the PWR. Instead, PWRs use two coolant loops to isolate the reactor from the turbine. Water passing through a PWR's primary loop is held at about 2200 psig to prevent boiling. Upon leaving the reactor, the primary coolant passes through heat exchangers (called steam generators) where water in the secondary loop is converted to the steam that drives the turbine. With either system, the steam passing through the turbine is condensed, any losses made up, and it is returned to the cycle as feedwater. Note that this feedwater enters the reactor in the case of a BWR (Figure 2.2) and enters the steam generators in the case of a PWR (Figure 2.3).

\subsection{BOILING WATER REACTORS}

Buoyant radioactive releases may occur if a significant amount of heated radioactive effluent is released. Therefore, leaks or breaks in pipes carrying steam or superheated water $\left(>100^{\circ} \mathrm{C}\right)$ are the likely sources for buoyant releases. The steam leaving the BWR reactor is radioactive since it contains traces of fission products and some activation products (such as nitrogen-16). Steam and hot water leaks of all sizes are possible. The largest steam leak would occur from the rupture of a main steam line; the largest superheated water release would occur from the break of a main feedwater line just outside of containment. This study determined the amounts of steam released from a main steam line break and from a feedwater line break since they represent upper limits of releases. Smaller potential leaks are described in a general manner with their duration and possible effluent release points identified. 
Typically, a BWR has four steam lines exiting the containment and entering the turbine building. A break in one of these lines gives, by far, the largest steam leak expected outside of containment and is analyzed in Chapter 15 of all BWR Final Safety Analysis Reports (FSARs). Only steam exits for the first second or two; this is followed by a steam water mixture because of swell in the liquid level in the core. Since the water in a BWR is much more contaminated than the steam, most of the activity is released in this two-phase mixture. In addition the large coolant loss can threaten to uncover the core. The core is protected by the emergency core cooling system and by main steam isolation valves (MSIVs) that are designed to automatically close within 5 to 10 seconds.

Many other steam leaks are possible but they will result in a smaller leak rate and a lower total amount of steam released. Section 4.0 discusses those other breaks although primary emphasis is placed upon the main steam line break accident. Section 4.0 also discusses the locations where the steam would exit the plant for the entire range of steam leaks.

Leaks of superheated water $\left(>100^{\circ} \mathrm{C}\right)$ can result in buoyant releases. The largest radioactive liquid flowrate in a BWR is the feedwater flow. Some plants pass the entire feedwater flow through only one line at some point downstream of the feedwater heaters. A break in this line would give the maximum liquid leak rate. In addition, because the feedwater at this point has the highest temperature of any liquid outside of containment, a higher percentage of the feedwater would flash in a break of this line than in a break of any other line. Thus, a break in a feedwater line between the last feedwater heater and the containment boundary was selected as the accident giving the largest potentially buoyant release from leaks of flashing water outside of containment. The locations, sizes and release points of other smaller leaks are discussed in Section 4.

Flow through the air ejectors, which keep a vacuum on the condenser, represents a normal leak path to the environment; the effluents are at low temperature (about $38^{\circ} \mathrm{C}$ ) and of rather small volume $(\sim 0.014 \mathrm{~m} 3 / \mathrm{s})$ flowrate. The effluents are treated to minimize the release of radioactive material, because this is a normal path to the environinent. The treatment, which may include filtration and delaying the release, reduces any potential buoyancy.

\subsection{PRESSURIZED WATER REACTOR}

Failure of a stealn or feedwater line in a PWR will not normally result directly in a radioactive release because the secondary loop is normally not contaminated. The most significant radioactive buoyant releases from a PWR are likely to occur as a result of a steam generator tube failure, an accident which is analyzed in Chapter 15 of all PWR FSARs. Failure of one or more steam generator tubes causes leakage of radioactive primary coolant into the secondary system. The turbine and reactor are tripped soon thereafter to minimize the release and to protect the reactor. In most cases the condenser remains available to cool the steam produced. In this case the contaminated steam from 
the steam generator is directed to the condenser via the turbine from the turbine bypass line, a) where it is condensed. Most of the radionuclides in the secondary system will remain trapped within the secondary system. The exceptions are noble gases released to the atmosphere by the condenser air ejector system and, in the event of condenser leaks, radiation released to condenser coolant water loop. PWR air ejector effluents are not likely to be buoyant because they are similar to those of a BWR (i.e., $0.014 \mathrm{M}^{3} / \mathrm{S}$ and $38^{\circ} \mathrm{C}$ ). However the secondary coolant loop is not normally contaminated, therefore the air ejector effluent is unlikely to be treated before release to the environment. The technical specifications under which nuclear reactor power stations operate allow very little condenser leakage, and little radioactive is expected to enter the condenser cooling water loop. However, radioactivity entering the condenser cooling water logp could be released to the atmosphere if evaporative cooling towers are used. (b)

Atmospheric dump valves and/or safety relief valves on the steam lines leaving the generators are the sources of the largest radioactive releases following a steam generator tube rupture. These valves are opened only when the condenser is unable to handle the steam load or when the condenser is not available. When the condenser is available, the safety relief valves may be opened briefly to accomrnodate transients associated with the reactor trip, turbine trip and the turbine bypass system activation. When the condensers are available, steam "dumps" ranging from 30 seconds to 5 minutes in duration may occur immediately following a reactor/turbine trip due to a steam generator tube rupture. Relief valve pressure is typically 1200 psia, and radioactive superheated steam at about $149^{\circ} \mathrm{C}$ exits the valves, resulting in a buoyant plume.

A more serious situation exists if the condenser is unavailable, such as when loss of offsite power results in loss of the ability to pump cooling water through the condenser. In this case a sustained release of steam lasting up to 30 minutes may occur before the affected steam generator can be isolated and the release of contaminated steam stopped.

Leaks from breaks in PWR hot water lines are much less likely to cause a radioactive, contaminated plume than with BWRs. First, the secondary loop is not radioactive. Second, the bulk of the primary fluid is recirculated within the containment building. However, a portion of the primary fluid is continuously transferred to the auxiliary building (the letdown flow) for treatment to remove radionuclides and to adjust primary coolant chemistry. A break in this system could result in a significant release of steam within the auxiliary building. Another possible source of flashing fluid would be a leak in the residual heat removal system (RHR). Releases from the letdown system or from

(a) The turbine bypass line permits steam to go directly to the condenser from the steam-generators (Figure 2.3).

(b) Most of the activity would remain in the condenser cooling water as it passes through the cooling tower because most fission products would remain in the liquid water. The exception would be the noble gases and the contaminated water lost through cooling tower drift. 
the RHR system leak differ from the releases during a steam generator tube rupture accident in that they represent leaks that would exit the auxiliary building rather than through the main steam safety relief or atmospheric dump valves. These are discussed in Section 5.0 . 



\subsection{ATMOSPHERIC BEHAVIOR OF POTENTIALLY BUOYANT RELEASES}

This section outlines the mathematical relationships that are used to evaluate the atmospheric behavior of the potentially buoyant, radioactive releases that might follow breaches of a nuclear power plant's steam system. Ultimately, these or similar relationships are needed to answer three basic questions: What is the effective height of the release? What are the groundlevel concentrations beneath the plume? Will the ground beneath an elevated plume be contaminated by deposition of material by processes such as rainout?

The atmospheric behavior of the releases is treated in two steps. In the first step, the near field behavior of the plume is estimated assuming that the release characteristics are the primary driving force for interactions between the plume and the atmosphere. This is the step in which plume rise and condensation are evaluated. In the second step, the far field behavior of the plume, i.e., diffusion, is estimated. These estimates are based upon the prevailing atmospheric conditions and an assumption that material in the plume behaves in a passive manner.

For a more comprehensive discussion of plume rise, the literature reviews by Briggs (1969 and 1975) should be consulted. Gifford (1975) reviews diffusion models, and Meteorology and Atomic Energy - 1968 (S1ade 1968) and the Handbook on Atmospheric Diffusion (Hanna, Briggs and Hosker 1982) discuss both plume rise and diffusion. These works contain the bases for the equations presented here.

\subsection{NEAR FIELD BEHAVIOR}

The near field behavior of a plume is controlled by the initial characteristics of the release, its area, velocity, temperature, density, and composition. These variables can be combined to give three fluxes that are useful in estimating plume rise. The fluxes are: volume, momentum and buoyancy. By definition, the fluxes are vector quantities. The volume flux is given by

$$
\vec{v}_{0}=\vec{w}_{0} R_{0}^{2} \text {, }
$$

and the momentum flux is given by

$$
\vec{M}_{0}=\vec{w}_{0}\left|\vec{V}_{0}\right|
$$

where $\vec{w}_{0}$ is the exit velocity vector and $R_{0}$ is the exit radius. Both fluxes are normally directed vertically. However, they may be directed horizontally 
if a release enters the atmosphere through an opening on the side of a building. The two fluxes always have the same direction.

The buoyancy flux is given by

$$
\vec{F}_{0}=g\left(\frac{T_{0}-T_{a}}{T_{0}}\right)\left|\vec{V}_{0}\right| \vec{k}
$$

where $g$ is the gravitational constant, $T_{0}$ and $T_{a}$ are the initial effluent and atmospheric temperatures, respectively, and $k$ is a unit vector in the vertical. In this form, the buoyancy flux takes into account the effects of sensible heat. The buoyancy flux is always directed upward, and therefore, does not necessarily have the same direction as the volume and momentum fluxes. If the effluent has a molecular weight that is significantly different than that of air, the difference in molecular weight can be taken into account by dividing the temperatures in (3.3) by the respective molecular weights.

In the near field, plume rise estimates are made assuming conservation of momentum and buoyancy and a third relationship called the closure assumption. A common closure assumption (Hanna, Briggs and Hosker 1982) is that the increase in volume of a plume as it rises is directly proportional to the product of the current radius and vertical velocity. The proportionality constant has a value of 0.16 . Following from these assumptions, the radius of the plume is defined by

$$
R(z)=R_{0}+0.16 z
$$

where $z$ is the height above the release point. A similar closure assumption and the same relationship for plume radius (with $x$ replacing $z$ ) should be appropriate in the near field for plumes released horizontally with large momentum fluxes, because the near field plume growth is due to entrainment that results from the difference in velocities of the plume and the air.

The height of a plume released vertically, as a function of downwind distance $(x)$, is given by

$$
z(x)=1.6\left|\vec{F}_{0}\right|^{1 / 3} x^{2 / 3} U^{-1}
$$

where $U$ is the wind speed, assumed to be constant with height. In addition, the average vertical velocity is given by 


$$
\bar{w}=2.3\left(\left|\vec{F}_{0}\right| / z\right)^{1 / 3} .
$$

During the initial plume rise, the plume is assumed to be well mixed, and the edges of the plume are assumed to be marked by discontinuities in temperature, humidity and other plume constituents.

To evaluate the potential for condensation within the plume, temperature and concentration of water in the plume must be determined. Both of these quantities are estimated by assuming isobaric mixing of the initial effluent with increasing quantities of the ambient air. The plume temperature is given by

$$
T_{p}=T_{0}-\left[\frac{N_{a} \rho_{a} c_{p a}}{N_{a} \rho_{0} C_{p o}+N_{a} \rho_{a} C_{p a}}\right]\left(T_{0}-T_{a}\right)
$$

where the N's are the volumes mixed, the $\rho^{\prime} s$ are densities, the $c_{p}$ 's are specific heats at constant pressure, and the subscripts indicate initial effluent and ambient air respectively. Similarly, the specific humidity in the plume is given by

$$
q_{p}=\frac{n_{0} \rho+N^{a} \rho^{a}}{n \rho_{0}+n \rho q^{a}}
$$

where the specific humidity, $q$, is the ratio of the mass of water to the mass of moist air. The potential for condensation is evaluated by comparing $q_{p}$ with the saturation specific humidity $q_{s}$ at temperature $T_{p}$. It is convenient to let $N_{0}=1$ and work in terms of $N_{a}$.

The distance, $d$, from the release point to the point where a unit volume of effluent is diluted with $\mathrm{N}_{\mathrm{a}}$ volumes of air is given by

$$
d=6.3 R_{0}\left[\left(1+N_{a}\right)^{1 / 2}-1\right] .
$$

This distance is the distance along the plume, not necessarily the horizontal distance from the source. When the wind is calm, it is a vertical distance, and during moderate winds it is a slant range. 


\subsection{FAR FIELD BEHAVIOR}

In evaluating the far field behavior of potentially buoyant radioactive releases from power reactors, the primary emphasis is placed on estinating the ground-level, normalized concentration beneath the centerline of an elevated plume given by

$$
\frac{x}{\dot{Q}}=\frac{1}{\pi \sigma_{y} \sigma^{U}} \exp \left\{-\frac{1}{2}\left(\frac{h_{e}}{\sigma_{z}}\right)^{2}\right\}
$$

where $x$ is the ground-level concentration, $Q$ is the release rate, $U$ is the wind speed at release height, $\sigma_{y}$ and $\sigma_{z}$ are the lateral and vertical diffusion coefficients, respectively, and $h_{e}^{2}$ is the effective release height. The effective release height is a function of the actual release height, the elevation of the terrain, and the plume rise. The diffusion parameters are functions of the initial plume dimensions and the turbulence in the atmosphere.

A conservative method of estimating the effective release height, described in Regulatory Guide 1.111 (USNRC, 1977) is

$$
h_{e}=h_{s}+h_{r}+h_{t}-c
$$

where $h_{s}$ is the release elevation, $h_{r}$ is the plume rise, $h_{t}$ is the terrain elevation, and $c$ is a correction factor for downwash due to low vertical exit velocity during periods of high wind speeds. Of these factors $h_{s}$ and $h_{t}$ are constants and $c$ is a function of the ratio of the vertical component of the exit velocity and the wind speed; only $h_{r}$ requires further definition. Hanna, Briggs and Hosker (1982) give expressions for the final rise of vertically released buoyant plumes as functions of the buoyancy flux and atmospheric conditions. For stable atmospheric conditions the final plume rise is

$$
h_{r}=2.6\left(\left|\vec{F}_{o}\right| / U S\right)^{1 / 3}
$$

where $S$ is a stability parameter defined as

$$
S=\frac{g}{T_{a}}\left(\frac{\partial T_{a}}{\partial z}+0.01{ }^{0} \mathrm{C} / m\right) \text {. }
$$


For neutral atmospheric conditions, the final plume rise is given by

$$
n_{r}=1.54\left\{\left|\vec{F}_{o}\right| /\left(U U_{\star}^{2}\right)\right\}^{2 / 3} h_{s} 1 / 3
$$

where $U_{\star}$ is the friction velocity, i.e., a scaling velocity for wind speeds near the surface. The friction velocity can be estimated from the low-level wind speed observations using the logarithmic wind profile (see Hanna, Briggs and Hosker 1982).

A third expression is given for use in unstable atmospheric conditions, however, that equation has little basis in observation. It should be conservative to use the neutral plume rise expression in unstable atmospheric conditions.

Many of the potentially buoyant releases at nuclear power plants could result in plumes with an initial horizontal momentum flux rather than a vertical flux. Although these initially herizontal plumes may rise, generally accepted methods for estimating the rise have not been identified. Intuitively, it is estimated that these plumes would result in concentrations near the source that are equal to the concentrations from ground-level releases and concentrations well downwind of the source that are similar to concentrations from elevated plumes. At intermediate distances, it is anticipated that there would be a relative concentration minimum associated with plume lift-off and a relative maximum following plume level-off. Further definition is needed in this area.

The diffusion parameters, $\sigma_{y}$ and $\sigma_{z}$, can be estimated in the usual manner using curves that give values as functions of downwind distance and stability. For consistency, however, it is appropriate to take into account the initial plume growth, which is not dependent upon atmospheric stability.

The first step in determining the parameter values is to compute the downwind distance at which atmospheric diffusion processes become dominant. For vertical releases, this distance is assumed to be the distance at which the plume levels off. For horizontal releases, it should be conservative to estimate the distance as if the release were vertical. Equating $h_{r}$ in (3.12) and (3.14) with $z(x)$ in (3.5) gives expressions that can be solved for the distance at level off. For stable atmospheric conditions this distance, denoted by a subscript $f$, is given by

$$
x_{f}=2.07 \text { U S }-1 / 2
$$


and for neutral conditions it is given by

$$
X_{f}=0.94\left(\left|\vec{F}_{o}\right| U\right)^{1 / 2} U_{\star}^{-2} h_{s} 1 / 2
$$

The distance that the plume travels between the point where it enters the atmosphere and where the diffusion process becomes dominant is, then approximately

$$
d_{f}=\left(x_{f}^{2}+h_{r}^{2}\right)^{1 / 2} .
$$

Equation (3.4) can be used to determine the plume radius at this point by substituting $d_{f}$ for $z$. Finally, the initial diffusion parameter values can be estimated by dividing the plume radius by a constant. Choice of the constant value is somewhat arbitrary. A value of 2.15 corresponds to an assumption that $90 \%$ of the material released is within the plume as defined by the radius at level off. This is the assumption that is commonly made when estimating diffusion coefficients from visible plumes. A value of 3.0 would correspond to an assumption that $99.7 \%$ of the material is within the plume. The initial values of the diffusion parameters are assumed to be:

$$
\sigma_{y}=\sigma_{z}=R\left(d_{f}\right) / 2.15
$$

To compute parameter values at downwind distances beyond $x_{f}$, the following procedure is used. The initial diffusion parameter values are used to compute a distance from an imaginary point source to the level-off point. This virtual distance, $x_{v}$, is a function of the prevailing atmospheric stability. It is common to have different virtual distances for $\sigma_{y}$ and $\sigma_{z}$. The virtual distances are used with $x_{f}$ and the actual distance, $x$, to determine effective distances, $x_{e}$, for estimation of downwind diffusion coefficients, e.g.,

$$
x_{e}=\left(x_{v}-x_{f}\right)+x
$$

The procedure for estimating diffusion parameters from effective distance rather than directly from actual distances can be accomplished manually if the diffusion parameters are defined graphically, as in Regulatory Guide 1.11l, and is easily accomplished in computer programs if the parameters are defined mathematically. 


\subsection{ADDITIONAL CONSIDERATIONS}

The equations presented in the last two sections generally relate to dry plumes released from an isolated stack for periods of the order of 15 minutes to an hour in duration. This section discusses the effects of departures from these conditions. Specifically covered are the effects of: moisture and condensation within the plume, multiple sources, building wakes, and release duration.

\subsubsection{Condensation}

The majority of the energy released does not contribute to plume rise unless condensation occurs. If it is assumed that saturated steam at $100^{\circ} \mathrm{C}$ is released into $10^{\circ} \mathrm{C}$ saturated air, $100 \%$ of the steam could be assumed to condense. TQ account for the release of latent heat, it would be necessary to increase $\vec{F}_{0}$ by a factor of about 16 . Plume rise in stable atmospheric conditions, which might accompany the $10^{\circ} \mathrm{C}$ saturated air, is proportional to the cube root of $\vec{F}_{0}$. Therefore, neglecting the latent heat underestimates plume rise by about a factor of 2.5. If a more realistic set of assumptions is made, the effect on plume rise of neglecting latent heat is less. Neglecting $50 \%$ condensation results in a factor of 2 underestimate of plume rise, and neglecting $20 \%$ condensation underestimates plume rise by a factor of about 1.4 .

These plume rise estimates are maxima. The condensation/evaporation processes proceed at a finite pace. If the plume does not remain in a supersaturated state long enough for droplets to grow and fall out of the plume, evaporation of the drops will reduce the latent heat available to increase the buoyancy.

While the plume is supersaturated, condensate droplets will form on available condensation nuclei; sources of condensation nuclei include ambient air entrained in the plume and volatile or particulate material released with the steam. If the condensate drops fall into unsaturated air below the main plume, they will begin to evaporate. If they evaporate completely, a new plume consisting of the condensation nuclei will be formed below the main plume. This process could result in separation of species released with the steam. Noble gases are likely to remain with the upper plume and the remainder of the material is likely to be associated with the lower plume.

Rather than attempt to account for the condensation and evaporation that may take place in the plume, plumes have been assumed to be dry for purposes of plume rise estimates. This assumption will result in ground-level concentration estimates that have higher maxima and maxima closer to the release point that would result if condensation and evaporation effects were treated quantitatively. In general the assumption should lead to conservative estimates of off site exposures. However, there may be circumstances when it is not conservative.

If the condensation drops do not fully evaporate as they fall, condensation nuclei in the drops and material scavenged by the drops during their fall 
will be deposited on the surface. The material from the release point to the point of impact is a function of the velocity of the plume, the rate of drop growth, the terminal velocity of the falling drop, and the wind speed. As a limiting case to estimate this distance, it is useful to assume that a fully formed drop is contained in the plume when it is released and determine the drop's trajectory. A suitable approximation of this trajectory can be made using the equations for uniformly accelerated motion between the release point and the point where the drop reaches its terminal velocity, and the equations for unaccelerated motion between that point and the drop's impact on the surface.

\subsubsection{Multiple Release Points}

Equations (3.12) and (3.14) are intended for use with isolated, single stacks or vents. Occasionally stacks or vents are situated close enough together that their plumes will merge as the plumes rise. When this happens, some additional rise can be expected. In nuclear power plants, the vents for atmospheric dump valves and safety valves along the main steam lines may be sufficiently close together for this to occur. Briggs (1974) gives the most commonly used procedure for estimating the plume rise for multiple sources. Hanna (1974) also provides a procedure, although it has not been tested with data.

The concept behind Briggs' procedure is to estimate the rise for one plume and then apply a correction factor that takes into account the number of release points, the spacing between release points and the predicted plume rise for a single source. The enhancement factor is defined as

$$
E_{n}=\left(\frac{N+\phi}{1+\phi}\right)^{1 / 3}
$$

where $\mathrm{N}$ is the number of release points and $\phi$ is

$$
\phi=6\left\{\frac{(N-1) \Delta x}{N^{1 / 3} h_{r}}\right\}^{2 / 3}
$$

The spacing between vents is $\Delta x$. Clearly, $E_{n}$ is maximized when $\phi$ is a minimum. In the limit, $E_{n}$ approaches a value of $N^{1 / 3}$ for large $N$ and $h$ and small $\Delta x$. To approach an enhancement factor of 2 requires 8 vents, and to approach a factor of 3 requires 27 .

\subsubsection{Building Wakes}

Many of the potentially buoyant releases from nuclear power plants would not take place from isolated stacks or vents. Those releases that occur through short vents on roofs or through building sides may be affected by the 
distortions of the airflow and turbulence in the vicinity of the building complex. The streamlines may reduce the effective release height, and turbulence in the building wake may increase the rate at which diffusion takes place. The treatment of non-buoyant plumes released from roofs of reactor buildings is discussed in detail by Ramsdell (1983). The treatment recommended is based upon a comparison of predicted plume rise with the approximate top of the building wake. The literature on building wakes is thoroughly reviewed in Hosker (1981).

With a number of simplifying assumptions, the top of the building wake is given approximately by

$$
h^{\prime}=0.28 L_{s}\left(\frac{x}{L_{s}}\right)^{1 / 3}
$$

where $h^{\prime}$ is the height above the building, $x$ is the downwind distance from the upwind edge of the building, and $L_{s}$ is a scale length related to the dimensions of the upwind face of the building. Latting $L_{s}$ equal the square root of the area of the smallest building face is reasonable. The plume can be assumed to have escaped the building wake if, at some downwind distance, the effective release height minus the plume radius is greater than the sum of $h^{\prime}$ and the height of the roof of the tallest building in the reactor complex. Selection . of the downwind distance at which the comparison is made is arbitrary. For the current purpose, the comparison distance is $100 \mathrm{~m}$ or the distance to final plume rise, whichever is smaller.

If the plume rises above the building wake, it should be treated as an elevated release. On the other hand, if it does not, the conservative approach to estimating ground-level concentrations is to assume that the release takes place at ground-level in the building wake, at least part of the time.

\subsubsection{Release Duration}

The last factor to be considered here is the effect of release duration on plume rise and diffusion. The plume rise formulations considered by Briggs (1969 and 1975) and others are for continuous releases, and Gifford (1975) indicates that the diffusion coefficient parameterizations are generally appropriate for estimating concentrations for periods of 30 minutes to an hour. However, a number of the potentially buoyant releases from reactors may have durations that are significantly shorter than 30 minutes. The releases from steam line breaks and safety valves may be less than a minute in duration.

Wind speed distributions are generally positively skewed, i.e., the mean speed is larger than the modal speed. As a result, the average wind speed during a short-term release, for example a release of 1 minute duration, is likely to be less than the average for a longer period, say 15 minutes. Consequently, plume rise computed with (3.12) and (3.14) is likely to be low. However, the concentrations within the plume, estimated using (3.10) would tend to be higher 
if the shorter-term wind speed were used. These differences are likely to be small and tend to be offsetting. Therefore, they are not considered further.

Turner (1960) and Fohl (1967) have considered pulsed releases of stack effluents as a method of increasing plume rise. A pulsed release may form a vortex, and vortices tend to maintain their identity in the atmosphere longer than plumes. As a result, a buoyant vortex should rise farther than a buoyant plume. On this basis, (3.12) and (3.14) will be used without modification, as the net effect should be conservative.

The relationship between release duration and the diffusion coefficient magnitudes has been considered by a number of individuals. Gifford (1968) and (1975) indicates that a power relationship originally proposed by Stewart, Gale and Crooks (1954) is generally accepted as a method for correcting diffusion coefficients for averaging time. Assuming that the appropriate averaging time for the standard diffusion coefficient formulations is 30 minutes, the diffusion coefficient values for shorter releases is given by

$$
\sigma_{t}=\sigma_{0}\left(\frac{t}{30}\right)^{0.2}
$$

where $\sigma_{t}$ is the corrected value, $\sigma_{0}$ is the value for a 30 minute average, and $t$ is the averaging time.

Nickola (1971) presents measured diffusion coefficient data for six instantaneous, ground-level puff releases. For four of the releases the stability was about Pasquill-Gifford class 0 . On the average the oy values computed for these conditions at distances of 200 and $800 \mathrm{~m}$ were between 65 and $70 \%$ of the corresponding values estimated using Figure 1 of Regulatory Guide 1.145. Ramsdell (1971) compares lateral diffusion coefficients for short segments of 2 continuous plumes with the coefficients for longer-term concentration averages in the same plumes. The ratios between the short- and longerterm diffusion coefficients were smaller than expected from (3.23) for time ratios out to 30 . However, at larger time ratios, the diffusion coefficient ratios tended to become constant, at about the expected values. There is a relatively large scatter in data used by both Nickola and Ramsdell, but the general conclusion to be drawn is that diffusion coefficients for short-term releases are likely to be smaller than those estimated using the standard methods. The differences may be a factor of 2 or more.

The effects of overestimates in diffusion coefficient magnitudes are readily estimated using (3.10). Centerline, time-integrated concentration will be reduced in proportion to the reciprocal of the product of the diffusion coefficient overestimates, but the exponential term will increase in magnitude. Close to the source the increase in the exponential term is the dominant factor. For example, if both $\sigma_{y}$ and $\sigma_{z}$ are overestimated by a factor of 2, ground-level concentrations will be overestimated until $\sigma_{z}$ equals $1.04 \mathrm{~h}_{\mathrm{e}}$. Beyond that distance, ground-level concentrations will be underestimated. 
Overestimating $\sigma_{2}$ also reduces the distance to the ground-level concentration maximum; the magnitude of the maximum may or may not be affected by an overestimate of $\sigma_{z^{*}}$. In the special cases treated by Gifford (1968) in which $\sigma_{y}$ is proportional to $\sigma_{z}$, the maximum time-integrated concentration is not affected by changing the distance to the maximum. In that case, the maximum is reached when $\sigma_{z}$ equals $\sqrt{2} h_{e}$.

Assuming that $h_{e}$ is $30 \mathrm{~m}$, the effects of a factor of 2 overestimate of $\sigma_{z}$ can be further evaluated. The overestimate of $\sigma_{z}$ gives conservative estimates of the ground-level, time integrated concentration until $\sigma_{z}$ grows to $31.2 \mathrm{~m}$, and the ground-level maximum occurs when $\sigma_{2}$ equals $42.4 \mathrm{~m}$. Using Figure 2 in Regulatory Guide 1.145 to evaluate these distances, the concentration estimates are conservative to a distance of about $1500 \mathrm{~m}$ in $\mathrm{E}$ stability, when the maximum is estimated to occur at about $2500 \mathrm{~m}$. If $\sigma_{z}$ were one-half of the $E$ stability value in the figure, the maximum would actualiy occur at about $10 \mathrm{~km}$. The more stable the atmosphere, the farther downwind the assumption of continuous plume diffusion coefficients remains conservative and the fartherit is to the maximum concentration.

In summary, the effects of moisture and release duration may affect plume rise and diffusion coefficient values, respectively, but the effects may be neglected without sacrificing conservatism, particularly near the release point. The effects of moisture should be considered with respect to condensation and subsequent washout of material contained in the plume. The effects of multiple release points on plume rise can be estimated using Briggs' relationship, but the effects are likely to be small, i.e., less than a factor of 2 . Finally, the potential interaction between a plume and the reactor complex can be evaluated, at least qualitatively, by comparing the final plume rise with the vertical extent of the wake. 



\subsection{BOILING WATER REACTOR RELEASES}

Steam leaks and superheated water leaks outside of containment are the only sources of potentially buoyant plumes from BWRs. Superheated water will flash to form a steam-water mixture at $100^{\circ} \mathrm{C}$. The temperature of the effluent from steam leaks will range from $100^{\circ} \mathrm{C}$ up to $150^{\circ} \mathrm{C}$, the maximum superheat resulting from expansion of steam from reactor conditions.

The detailed layout and design of nuclear plants, even for those of the same vendor, varies considerably from site to site. Furthermore, the path to the environment depends to what extent upon the location and size of the leak. The approach taken here is to evaluate the largest expected leak from each of the likely release points in several representative power plants and to describe representative locations and layouts of these release points. Releases from intermediate and small leaks would be expected either to exit the plant through the same release points as the large leaks or through the heating and ventilation system's exhaust vents. In this manner, a generic picture of the amounts of steam as well as the locations and elevations at which such releases would be expected to occur is obtained.

\subsection{STEAM LEAKS}

Steam leaks ranging in size from trace quantities to the largest expected, that from a break of a main steam line, are possible with a BWR. Leaks can occur within the reactor building (or auxiliary building as certain parts of the reactor building are called in some plants) as well as in the turbine building. The largest analyzed leak, the break of a main steam line, is discussed first.

Figure 4.1 presents a schematic diagram of a steam line break within the steam tunnel. The steam tunnel is a pressure-resistant structure that encloses the steam and feedwater lines from the point where they exit the containment until they reach the turbine operating deck. The steam tunnel acts to prevent the escaping steam from entering the reactor building. Depending upon the specific plant and the location of the break, the escaping steam may reach the environment via blowout panels located in the reactor building, blowout panels located in the steam tunnel or by passing through the turbine building or a combination of all three of these exits.

An examination of Figure 4.1 shows that other break locations are possible. Breaks within containment would not result in a buoyant plume unless there was a loss of containment which would be an entirely different class of accident. Breaks inside that portion of the steam tunnel within the turbine building would result in a portion of the steam flow exiting the steam tunnel blowout panels and a portion exiting the turbine building. A break inside the turbine bay would be expected to exit the turbine building. Blowout panels per se are not provided in many turbine buildings. Instead, turbine buildings are designed with sheetmetal walls above the turbine deck which serve the same 


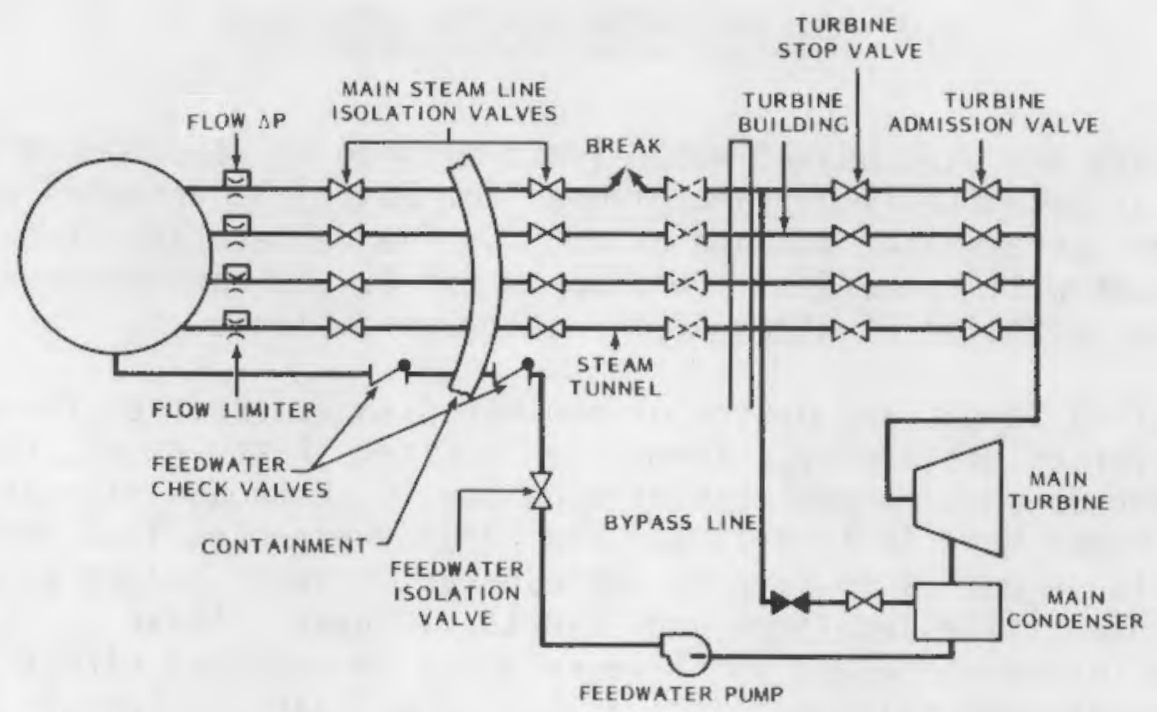

FIGURE 4.1. Schematic of a Main Steam Line Break Inside the Steam Tunnel

purpose as blowout panels in relieving building pressure. In short, the steam released from a main steam break will, depending upon the specific plant, exit the reactor building vent, steam tunnel blowout panels or via the turbine building.

Final Safety Analysis reports for BWRs with General Electric Mark I, Mark II, and Mark III containments were examined to obtain representative building layouts and likely release points for steam line breaks (Figures 4.24.4). Though reactor design does not necessarily dictate the design of release points, information on the plant layouts of the three generations of BWRs was obtained.

Browns Ferry (Figure 4.2) is a three unit MK-I BWR plant. The steam released by a main steam line leak is vented directly into the turbine building. Thus it would be expected that the steam would exhaust horizontally to the atmosphere somewhere between the operating floor 9 meters above grade and the turbine building roof 32 meters above grade. The turbine building volume would be used to determine overpressures resulting from steam line breaks. The effect of the building volume on plume characteristics has not been estimated.

The two unit, MK-II Susquehanna Nuclear Plant is shown in Figure 4.3. The system to vent steam from a main steam line leak makes use of a reactor building vent, steam tunnel blowout panels and venting to the turbine building. A leak in that portion of the steam tunnel lying within the reactor building would result in a portion of the steam exiting the reactor building vent through blowout panels located 41 meters above grade and the remainder entering the turbine building through one-way relief panels. A portion of this latter flow would exit the steam tunnel blowout panels located 12.2 meters above grade on the east side on the turbine building about 9.1 meters from the reactor building (see Figure 4.3) with the remainder exiting via the turbine building. 

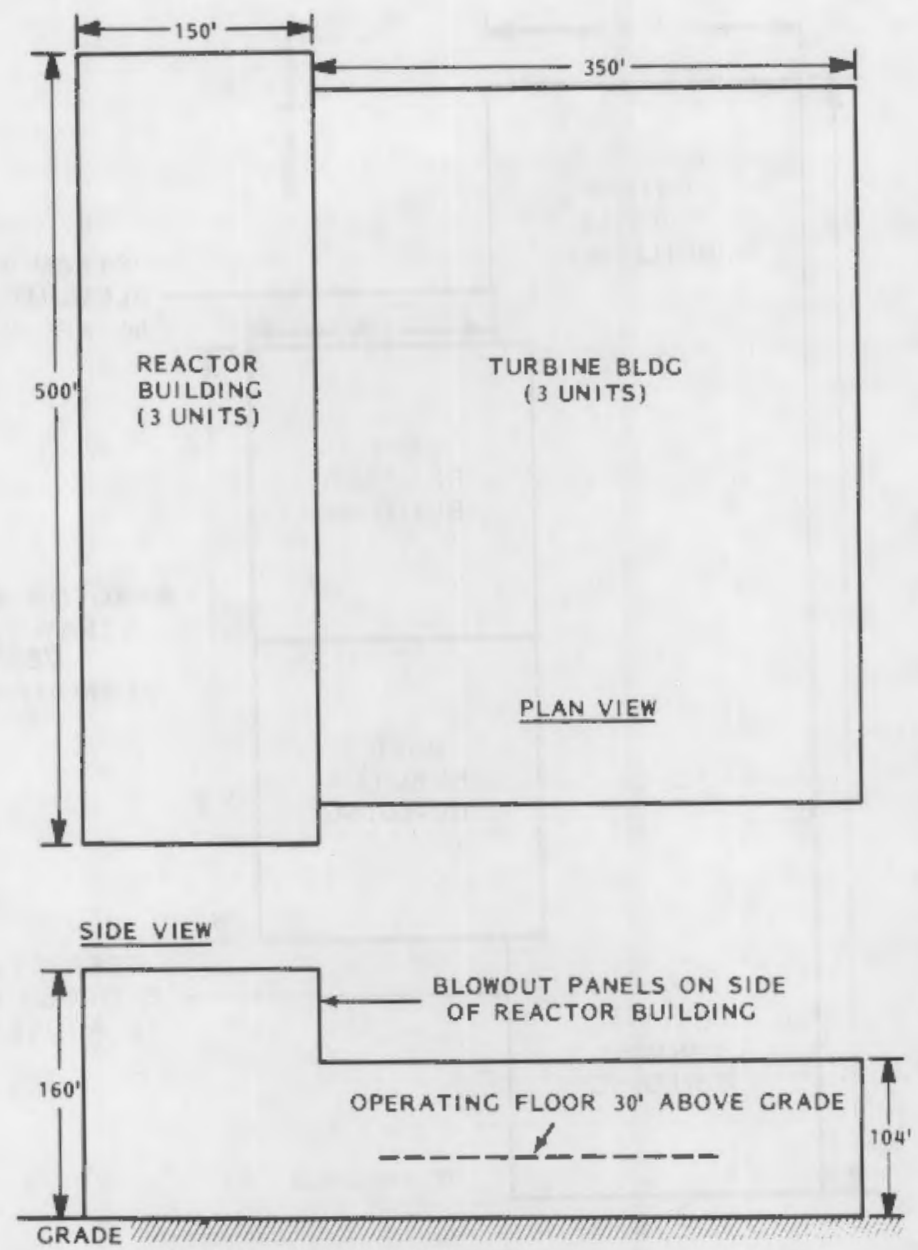

FIGURE 4.2. Plan and Side View of Unit 3 Browns Ferry Nuclear Station

Since the Unit 1 and Unit 2 turbine buildings are not partitioned by a cominon wall, the entire volume of these buildings is used to determine the overpressure resulting from the steam release. Any release through blown out walls would be expected to occur above the operating floor which is located 15.2 meters above grade.

The layout of the two unit, MK-III Grand Gulf Nuclear Station is shown in Figure 4.4. The reactor building is equipped with a steam tunnel blowout shaft with blowout panels located about 24.4 meters above grade on the side of the building (see Figure 4.4). Steam exiting the turbine building would probably leave at or above the elevation of the operating floor 10.4 meters above grade.

The total amounts of steam and water that would be released from a steam line break are given for three reactors in Table 4.1. The flowrates and temperatures are those that would exist after an isenthalpic expansion from the conditions within the steam line to one atmosphere, and assuming a low velocity for steam exiting the reactor or turbine building. Initially only steam at 

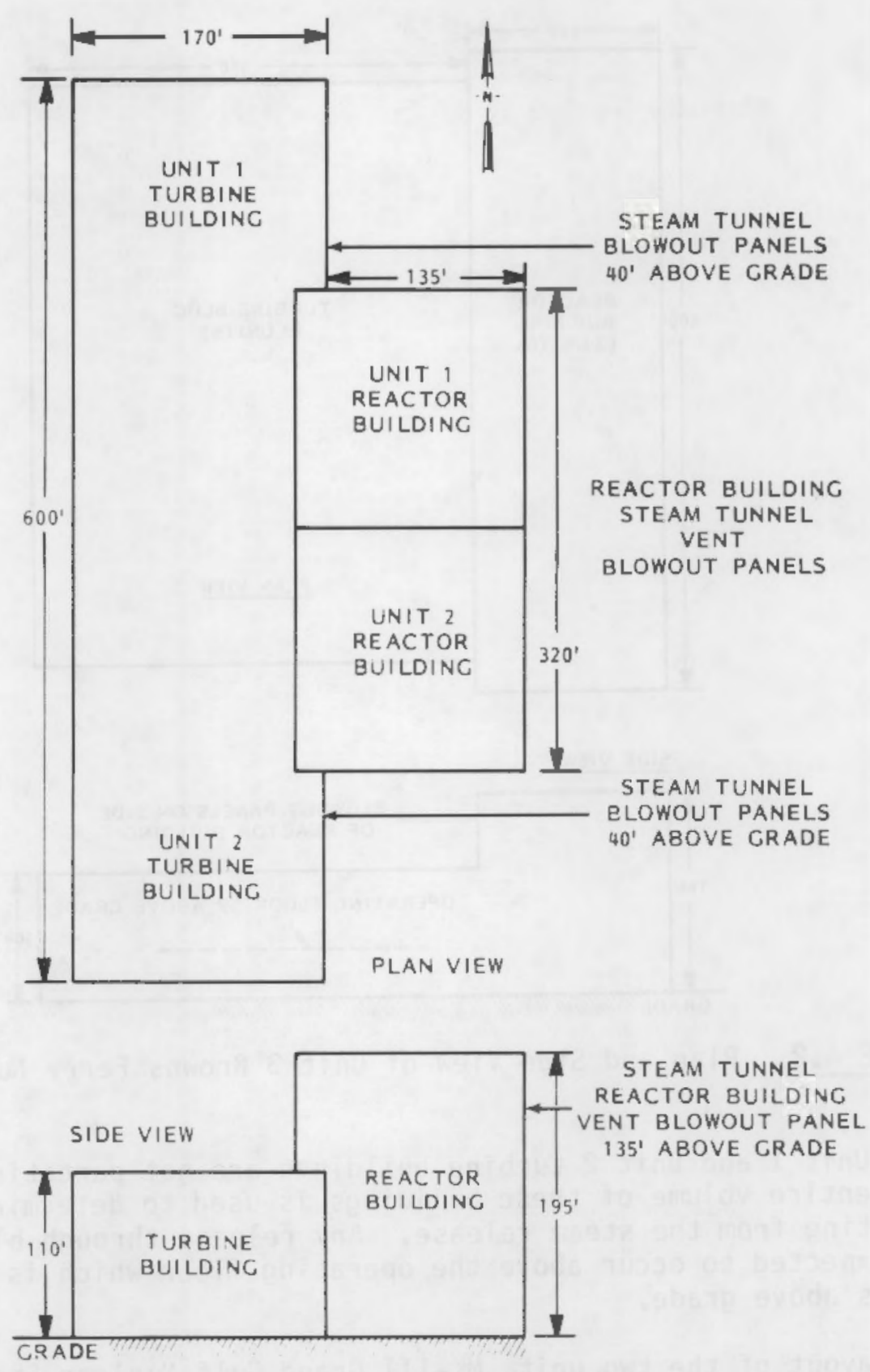

FIGURE 4.3. Side and Plan Views of Susquehanna Nuclear Station 

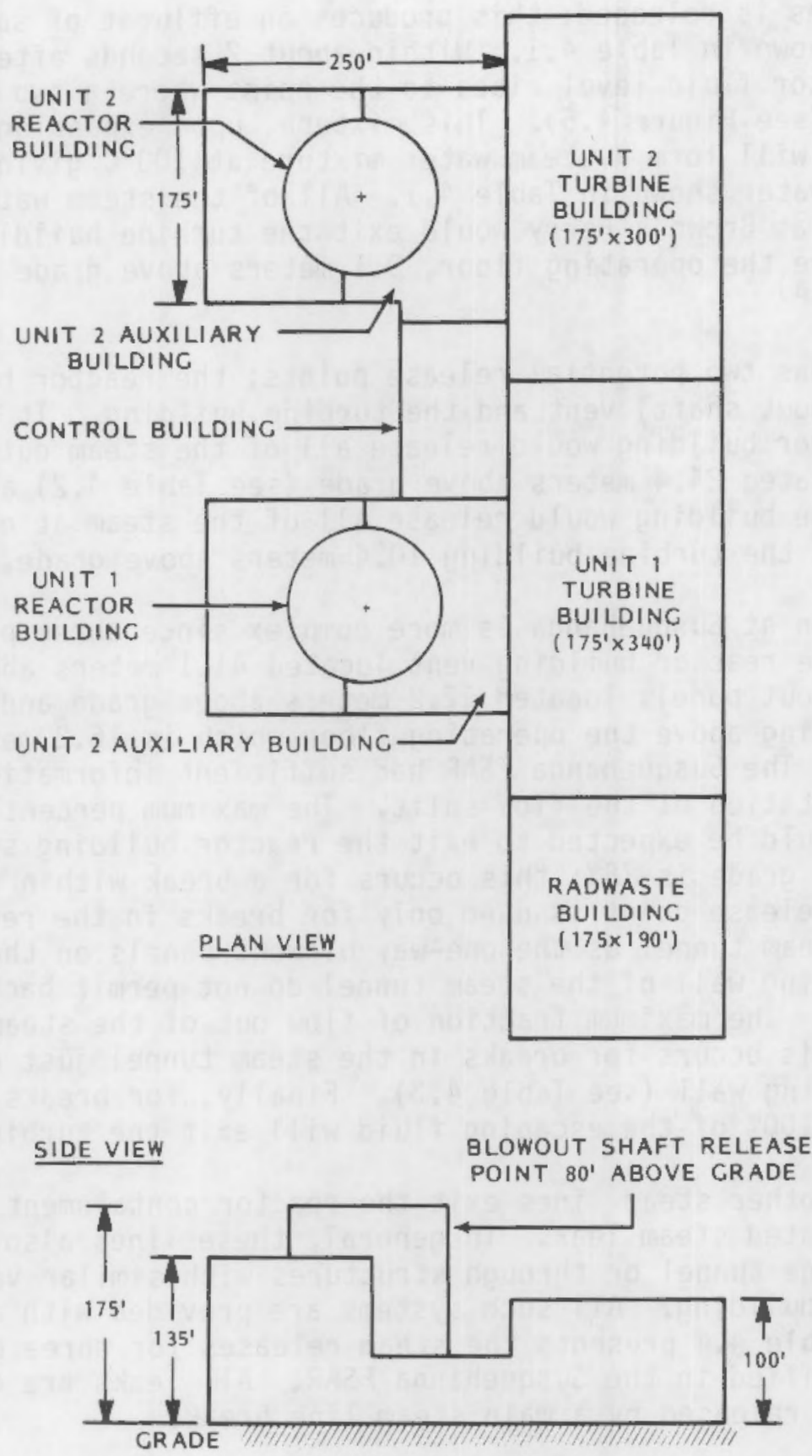

FIGURE 4.4. Simplified Plan View and Side View of Unit 2 Grand Gulf Nuclear Station 
reactor conditions is released; this produces an effluent of superheated steam at about $149^{\circ} \mathrm{C}$ shown in Table 4.1. Within about 2 seconds after the break occurs, the reactor fluid level rises to the point where a two phase mixture exits the break (see Figure 4.5). This mixture, upon expanding to one atmosphere pressure, will form a steam water mixture at $100^{\circ} \mathrm{C}$ giving the amounts of $100^{\circ} \mathrm{C}$ steam and water shown in Table 4.1. All of the steam water released by a steam line break at Brown's Ferry would exit the turbine building, probably at an elevation aboye the operating floor, 9.1 meters above grade or through building drains. (a)

Grand Gulf has two potential release points; the reactor building (main steam tunnel blowout shaft) vent and the turbine building. It appears that a leak in the reactor building would release all of the steam out the reactor building vent located 24.4 meters above grade (see Table 4.2) and that a leak inside the turbine building would release all of the steam at or above the operating deck of the turbine building 10.4 meters above grade.

The situation at Susquehanna is more complex since three potential release points exist: the reactor building vent located 41.1 meters above grade, the steam tunnel blowout panels located 12.2 meters above grade and that portion of the turbine building above the operating floor which is 16.2 meters above grade (see Table 4.2). The Susquehanna FSAR had sufficient information to allow an approximate computation of the flow split. The maximum percent of the steam and water that would be expected to exit the reactor building steam tunnel vent 41.1 meters above grade is $75 \%$; this occurs for a break within the reactor building. This release point is used only for breaks in the reactor building portion of the steam tunnel as the one-way blowout panels on the reactor building-turbine building wall of the steam tunnel do not permit backflow from the turbine building. The maximum fraction of flow out of the steam tunnel blowout panels is $70 \%$; this occurs for breaks in the steam tunnel just downstream of the reactor building wall (see Table 4.3). Finally, for breaks in the turbine building proper, $100 \%$ of the escaping fluid will exit the turbine building.

A number of other steam lines exit the reactor containment and could be a source of superheated steam leak. In general, these lines also pass through the main steam line tunnel or through structures with similar venting to protect the reactor building. All such systems are provided with automatic isolation valving. Table 4.4 presents the steam releases for three of the largest such breaks identified in the Susquehanna FSAR. All leaks are considerabiy smaller than that released by a main steam line break.

(a) It has not been determined what fraction of the water released from a steam line break would also exit the reactor and/or turbine buildings concurrent with the steam. It could range from nearly $100 \%$ for that mixture exiting the blowout panels in the steam tunnel for a break located there to a very small fraction of that portion of the flow exiting the turbine building since most of the water would probably exit through turbine building drains. 
TABLE 4.1. Effluents From a Main Steam Line Break*

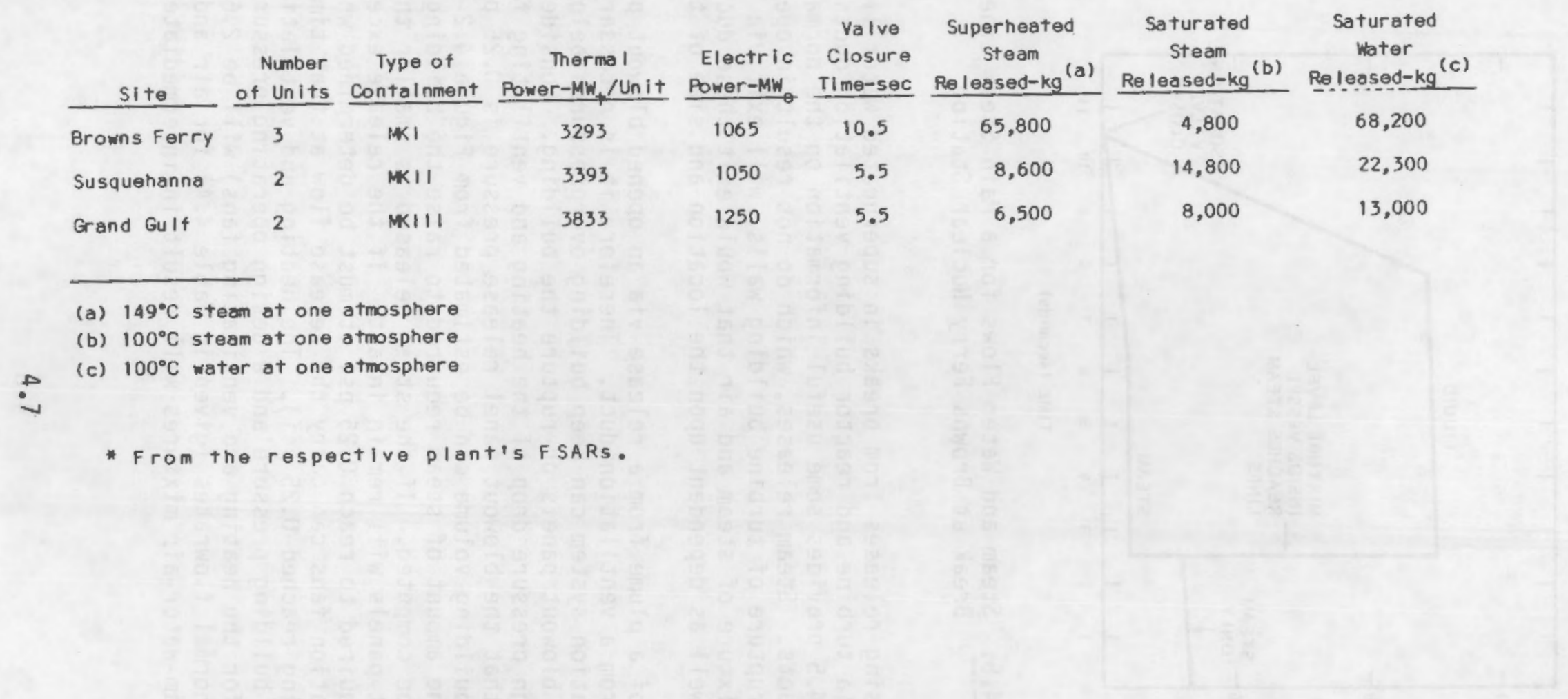




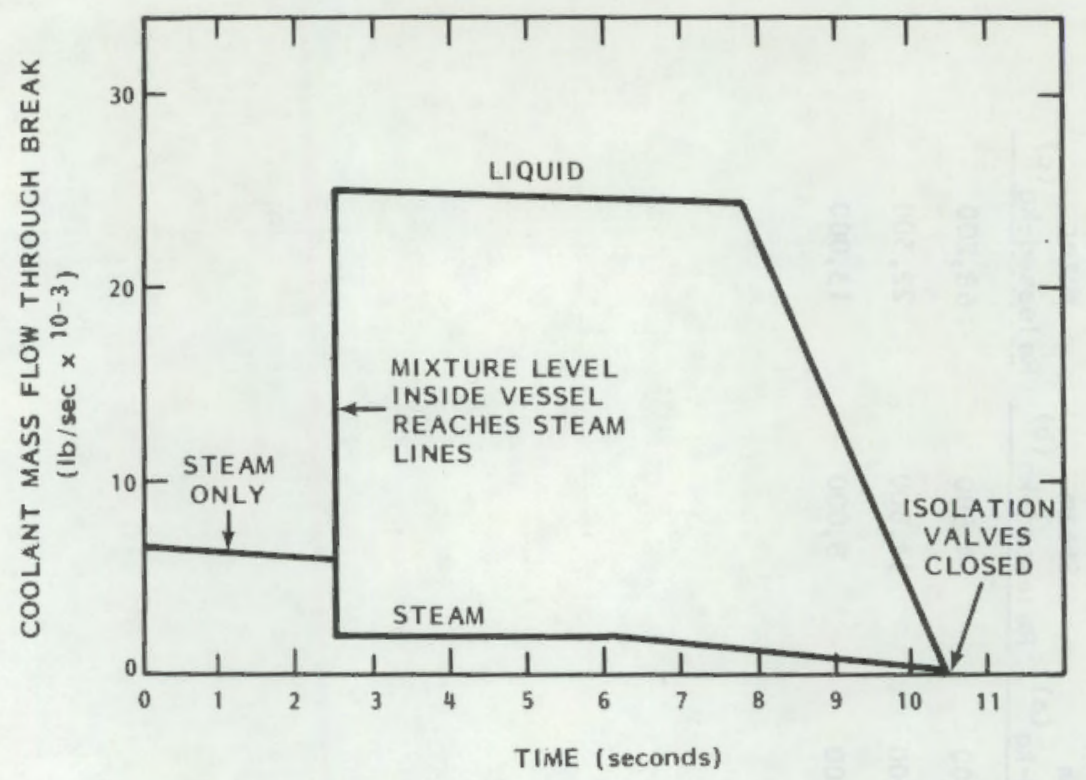

FIGURE 4.5. Steam and Water Flows for a Main Steam Line Break at Browns Ferry Nuclear Station

Before discussing releases from breaks in superheated water lines, the exhaust of steam via turbine and reactor building ventilation ducts will be discussed. Table 4.5 provides some useful information on the normal releases from ventilation ducts. Steam releases, which do not result in operation of blowout panels or rupture of turbine building walls, will exit via the ventilation ducts. The mixture of steam and air that would exit these ducts would be time dependent as well as dependent upon the location and size of the release.

The behavior of a plume from a release via an opened blowout panel may differ from that from a ventilation duct. Therefore it is necessary to determine if the ventilation system can keep building overpressures below the value needed to activate blowout panels or rupture the building. Consider, for example, that the design pressure drop of the heating and ventilating fans is one inch of water and that the blowout panel release pressure is 0.25 psi (Brown's Ferry FSAR). The building volume can be estimated from Figure $4.2-4.4$ or from the plant FSAR. The amount of steam required to raise the building pressure to $0.25 \mathrm{psi}$ can then be computed. If the steam released is smaller than that amount, the blowout panels will remain intact. If the release exceeds the amount of stearn required to reach $0.25 \mathrm{psi}$ it must be determined whether the heating and ventilation fans can carry the release flow at that time (the time at which the building reached $0.25 \mathrm{psi}$ ). The heating and ventilation flow (assuming 0.25 psi building pressure and a design operating pressure drop of one inch of water for the heating and ventilating fans) will be 2.6 and 3.3 times that of the normal flowrates (given in Table 4.4) for air and steam, respectively. Steam-water-air mixtures will result in intermediate ratios. If 
TABLE 4.2. Release Points for Main Steam Line Breaks

\begin{tabular}{|c|c|c|c|c|}
\hline Plant & Vent & $\begin{array}{l}\text { Elevation } \\
\text { Above } \\
\text { Grade-m } \\
\end{array}$ & Area $-m^{2}$ & Direction of $\mathrm{Flow}$ \\
\hline Browns Ferry & Turbine building & 9.1 (a) & $\begin{array}{l}\text { Unknown } \\
>557 \\
\text { reasonable }\end{array}$ & $\begin{array}{l}\text { Probably hori- } \\
\text { zontal }\end{array}$ \\
\hline \multirow[t]{3}{*}{ Susquehanna } & $\begin{array}{l}\text { Reactor building } \\
\text { main steam tunnel } \\
\text { blowout shaft vent }\end{array}$ & 41.1 & 35.3 & Horizontal \\
\hline & $\begin{array}{l}\text { Steam tunnel } \\
\text { blowout panels }\end{array}$ & 12.2 & 19.5 & Horizontal \\
\hline & Turbine building & $15.2^{(a)}$ & $>557$ & $\begin{array}{l}\text { Probably hori- } \\
\text { zontal }\end{array}$ \\
\hline \multirow[t]{2}{*}{ Grand Gulf } & $\begin{array}{l}\text { Reactor building } \\
\text { main steam tun- } \\
\text { nel blowout shaft } \\
\text { tunnel vents }\end{array}$ & 24.4 & 17.8 & Horizontal \\
\hline & Turbine building & $10.4^{(a)}$ & $\begin{array}{l}\text { unknown } \\
>557 \\
\text { reasonable }\end{array}$ & $\begin{array}{l}\text { Probably } \\
\text { horizontal (a) }\end{array}$ \\
\hline
\end{tabular}

(a) Assumes turbine building walls will rupture above the operating floor elevation.

(b) $557 \mathrm{~m}^{2}$ from Susquehanna FSAR.

IABLE 4.3. Approximate Main Steam Line Break Flow Splits at Susquehanna

\begin{tabular}{|c|c|c|c|}
\hline Location of Break & $\begin{array}{l}\text { Flow Out } \\
\text { the Reactor } \\
\text { Building Vent } \\
\end{array}$ & $\begin{array}{l}\text { Steam Tunnel } \\
\text { Blowout } \\
\text { Panels } \\
\end{array}$ & $\begin{array}{l}\text { Turbine } \\
\text { Building }\end{array}$ \\
\hline Reactor Building & $75 \%$ & 15 & 10 \\
\hline $\begin{array}{l}\text { Steam tunnel just } \\
\text { outside of reac- } \\
\text { tor building }\end{array}$ & 0 & 70 & 30 \\
\hline Turbine deck & 0 & 0 & 100 \\
\hline
\end{tabular}


TABLE 4.4. Other Steam Breaks at Susquehanna Nuclear Station

\begin{tabular}{|c|c|c|}
\hline System & Released Location & $\begin{array}{l}\text { Total Stearl } \\
\text { Released } \mathrm{kg}(\mathrm{a}) \\
\end{array}$ \\
\hline $\begin{array}{l}\text { High pressure core } \\
\text { injection (HPCI) } \\
\text { penetration room }\end{array}$ & Reactor building & 1320 \\
\hline HPCI pump room & Reactor building & 3170 \\
\hline $\begin{array}{l}\text { Reactor heat removal } \\
\text { system }\end{array}$ & Reactor building & 3950 \\
\hline
\end{tabular}

(a) $149^{\circ} \mathrm{C}$ steam; leak stopped in $30-60$ seconds.

TABLE 4.5. Heating and Ventilation Flows

Elevation

\begin{tabular}{|c|c|c|c|c|}
\hline Plant & Vent & Above Grade m & Flow $\mathrm{m}^{3} / \mathrm{s} /$ Unit & Velocity $\mathrm{m} / \mathrm{s}$ \\
\hline \multirow[t]{2}{*}{ Browns Ferry } & $\begin{array}{l}\text { Reactor } \\
\text { building }\end{array}$ & $48.8(a)$ & $\begin{array}{l}35.4 \text { (when heating) } \\
70.8 \text { (when cooling) }\end{array}$ & $=-$ \\
\hline & $\begin{array}{l}\text { Turbine } \\
\text { building }\end{array}$ & $31.7(a)$ & $\begin{array}{l}29.3 \text { (winter minimum) } \\
127 . \quad \text { (summer) }\end{array}$ & - \\
\hline \multirow[t]{2}{*}{ Grand Gulf } & $\begin{array}{l}\text { Reactor } \\
\text { building }\end{array}$ & $42.7(b)$ & 16.5 & 17.0 \\
\hline & Turbine & $30.5(c)$ & 2.4 & 4.6 \\
\hline
\end{tabular}

(a) Located on building roofs.

(b) Located on building side.

(c) Discharge point is penthouse on the building roof with louvered sides.

the volumetric flowrate of the steam being released to the building exceeds the ventilation system's flowrate at that time, the pressure will rise and the blowout panels will open.

\subsection{SUPERHEATEU LIQUID LINE BREAKS}

Upon depressurization, superheated water flashes to form a $100^{\circ} \mathrm{C}$ steamwater mixture. The hotter the water, the higher the quality of the steam-water mixture formed (i.e., more steam). Because the feedwater flow is the largest 
superheated water flow outside of containment and the temperature of the feedwater between the last heater and the containment boundary is one of the highest water temperatures in the plant, a break in this region (see Figure 4.6) will give the largest steam release from superheated water. The feedwater lines generally pass through the steam tunnel; therefore, the release points would be similar to those from a main steam line break (see Section 4.1).

The conditions at Susquehanna are typical. The feedwater flow is $1690 \mathrm{~kg} / \mathrm{s}$. The feedwater is at a temperature of $195^{\circ} \mathrm{C}$, this will result in $18 \%$ of the feedwater flashing to $100^{\circ} \mathrm{C}$ steam in the event of a break. The time that would elapse between the occurrence of a break and stopping of the leak is somewhat uncertain. Consider first the largest break. A check valve on the reactor containment boundary prevents backflow from the reactor. Once feedwater flow to the reactor stops, the reactor level begins to fall. Therefore, the automatic control system signals the pumps to increase their flow. The event is brought to a halt at about 30 seconds when the reactor is scrammed on low water level. The feedwater pumps are simultaneously tripped and begin to coast down. A reasonable approximation to obtain an upper limit that accounts for the increased flow through the break and for pump coast down time is to use one minute normal flow. This gives a total mass loss of $101,800 \mathrm{~kg}$ of which $18 \%$ or $18,300 \mathrm{~kg}$ would be $100^{\circ} \mathrm{C}$ steam and the remainder $(83,500 \mathrm{~kg})$ would be $100^{\circ} \mathrm{C}$ water. A smaller leak would lead to scram at a later time or possibly no automatic scram at all. However, the operator would receive an alarm for high temperature in the region of the break within 30 seconds and would be expected to take action. Thus the large break described above probably gives the largest release.

Most BWRs operate at similar conditions, therefore the mass flow can be scaled with sufficient accuracy for different plants by using the ratio of thermal power of other plants to that of Susquehanna (3393 $\mathrm{MW}_{\mathrm{t}}$ ).

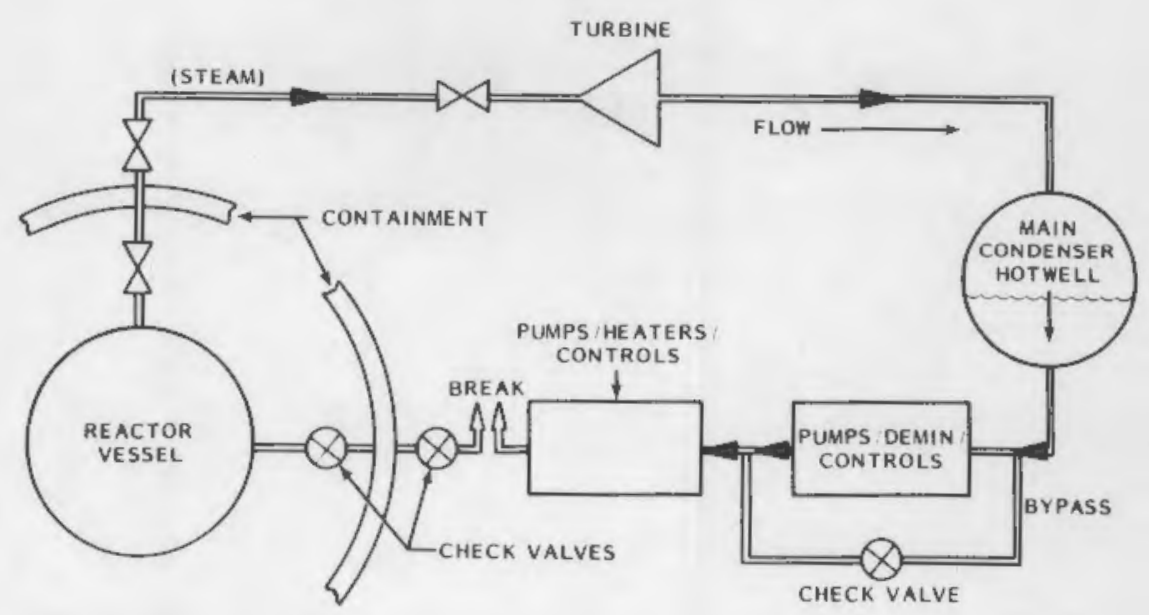

FIGURE 4.6. Schematic of Feedwater Line Break Between Heaters and Containment 
BWRs are equipped with full flow demineralizers. These combined with the stripping of the radioactive gases which occurs in the condenser, reduces the radioactivity level of the feedwater to about one hundredth that of the steam. Therefore, though feedwater breaks may release substantial amounts of steam, the steam is much less radioactive than that from a steam line break. 


\subsection{PRESSURIZED WATER REACTOR RELEASES}

The three events that may result in radioactive buoyant plume releases from PWRs have been identified in Section 2. These include a steam generator tube rupture followed by a reactor trip, a pipe break in the RHR system and a break in the letdown line piping outside of containment. Babcock \& Wilcox, Westinghouse, and Combustion Engineering PWRs were examined to evaluate consequences of potential releases from these events.

The most significant buoyant radioactive releases from a PWR will occur as a result of a steam generator tube rupture. A failure of one or more tubes causes leakage of radioactive primary coolant into the secondary system. The reactor and turbine are tripped soon thereafter to minimize the release and to protect the reactor. The dominant leakage path following this rupture results from the opening of atmospheric dump and/or safety relief valves. For all three reactor designs (i.e., B\&W, Westinghouse, CE) it is assumed that steam is released from the main steam line atmospheric dump or safety valves at constant mass flow rates for the entire release period. For all of the PWRs evaluated, this is probably not the most realistic case. The rated capacity of the valve(s) is greater than the assumed constant flowrate of the steam being released. As a result, the steam will most likely be released intermittently. In addition, the flow rate would actually be higher than these average flowrates at the beginning of the release and decrease below these values as the pressure decreases to the dump or safety valve closure set points. As the steam generator pressure decreases to the valve closure set point, the steam temperature as well as the mass flowrate through the valves will also decrease. This will correspondingly affect the temperature and velocity of the released steam. However, this was not taken into account for the data given in Tables $5.1,5.4$ and 5.6 .

The number of valves involved in a steam release will vary depending on their set point pressures and the highest pressure achieved in the steam generator. To exemplify this point, data on the dump and safety valves of the WNP $1 \& 4$ plants are given in Table 5.2 .

Though all four of the dump valves and all twenty safety valves are listed to open at 1220 psia and 1250 psia, respectively, common engineering experience indicates that these valves will open at different set points due to design error and/or calibration variances. According to Article NC-7000 of ASME Section III, main steam safety relief valves can have a set pressure error of $\pm 1 \%$. Applying this error range to the dump valves means that one or all four valves could possibly open as low as about 1207 psia, or as high as about 1233 psia, or at any pressure in between. Though the number and type of valves that opened in the steam generator tube rupture analyses reviewed for all three PWR types were not explicitly stated, it is assumed that steam is released through the minimum number of dump or safety valves needed to handle the total steam flow from each steam generator. If the steam generator pressure did reach the set point of all twenty safety valves at the same time (i.e., 1250 psia), the 
TABLE 5.1. Steam Release Conditions for a Steam Generator Tube Rupture With and Without Loss of Offsite Power for a Babcock \& Wilcox Reactor (WNP 1 \& 4 )

\begin{tabular}{|c|c|c|}
\hline Parameters & $\begin{array}{l}\text { With Loss of } \\
\text { Offsite Power }\end{array}$ & With No Loss of Offsite Power \\
\hline Temperature & $187^{\circ} \mathrm{C}$ & $187^{\circ} \mathrm{C}$ \\
\hline Velocity & 2 vents $\theta 120 \mathrm{~m} / \mathrm{s}$ & 2 vents $@ 163 \mathrm{~m} / \mathrm{s}$ \\
\hline Density & $0.480 \mathrm{~kg} / \mathrm{m}^{3}$ & $0.480 \mathrm{~kg} / \mathrm{m}^{3}$ \\
\hline Exit radius & 2 vents $0.53 \mathrm{~m}$ & 2 vents $0.53 \mathrm{~m}$ \\
\hline Flow rate & $\begin{array}{l}51.7 \mathrm{~kg} / \mathrm{s}(\mathrm{a}) \\
\text { each vent }\end{array}$ & $\begin{array}{l}70.4 \mathrm{~kg} / \mathrm{s}(\mathrm{a}) \\
\text { each vent }\end{array}$ \\
\hline Release time & 18 minutes & 3 minutes \\
\hline $\begin{array}{l}\text { Height of release } \\
\text { point }\end{array}$ & $21.3 \mathrm{~m}$ above grade & $21.3 \mathrm{~m}$ above grade \\
\hline
\end{tabular}

(a) This is an average flowrate for the entire release time TABLE 5.2. Atmospheric Dump and Safety Relief Yalve Setpoints
and Rated Flowrates for WNP 1 \& 4 (a)

\begin{tabular}{|c|c|c|c|c|}
\hline Type & $\begin{array}{c}\text { Number per } \\
\text { Steam Generator }\end{array}$ & $\begin{array}{c}\text { Setpoint Pressure } \\
\text { (psia) }\end{array}$ & $\begin{array}{l}\text { Rated Flow- } \\
\text { rate per valve } \\
\end{array}$ & $\begin{array}{c}\text { Exit Vent Radius } \\
\text { (meters) }\end{array}$ \\
\hline Dump Valve(b) & 2 & 1220 & $\begin{array}{l}75.6 \mathrm{~kg} / \mathrm{s} \\
1250 \mathrm{psia}\end{array}$ & 0.533 \\
\hline Safety Valves & 10 & 1250 & $\begin{aligned} 119.2 \mathrm{~kg} / \mathrm{s} \\
1325 \mathrm{psia}\end{aligned}$ & 0.254 \\
\hline Dump Valves* & 8 & 1205 & $\begin{array}{r}101.3 \mathrm{~kg} / \mathrm{s} \\
1050 \mathrm{psia}\end{array}$ & 0.533 \\
\hline
\end{tabular}

(a) WNP 1 \& 4 Have 2 Steam Generators

(b) Upstream of MSIVs

* Downstream of MSIVs and Used With Available Offsite Power Only 
secondary pressure would decrease below their closure set points very quickly and may open for only a few seconds. Typically, safety valve closure set points are between 50 and 75 psi below their opening set points.

Concerning leaks from PWR hot water lines, radioactive steam releases may occur for accidents involving rupture of the letdown line. Using information from the Midland 1 \& 2 FSAR (B\&W reactors) as a generic example for all three reactor types shows that reactor coolant is drawn from one of the reactor pressure vessel's cold legs at about 2150 psia through an $0.0635 \mathrm{~m}$ diameter pipe, and flows through the letdown heat exchanger at a maximum of $8.8 \times 10^{-3} \mathrm{~m} / \mathrm{s}$ before the line passes through containment. Typically, the reactor coolant at this point has been reduced to $49^{\circ} \mathrm{C}$. A rupture of the letdown line just outside of containment will result in a worst case loss of coolant accident and would quickly release reactor coolant to the auxiliary building at a flowrate much higher than the nominal maximum value. Normally, the letdown line isolation valves inside of containment will autgmatically close when this flowrate reaches a specific value (e.g., $1.26 \times 10^{-2} \mathrm{~m}^{3} / \mathrm{s}$ for Midland 1 \& $)$ and isolate the leak. At this high flowrate, however, the efficiency of the letdown heat exchanger would be affected 50 as to allow reactor coolant greater than $100^{\circ} \mathrm{C}$ to pass through it. Though a portion of the leaking coolant may flash to steam in this situation, one would not expect a large amount considering the automatic isolation of the letdown line valves. Any steam would be released to the atmosphere via the ventilation system through the auxiliary building stack. In the FSAR letdown line accident analyses, the licensees' usually take a conservative worst case approach and neglect the automation of the containment isolation valves, and assume the leak is isolated by operator intervention after a low pressure reactor trip and initiation of the emergency core cooling system. They also assume the reactor coolant leaking into the auxiliary building is between $100^{\circ} \mathrm{C}$ and the letdown heat exchanger inlet temperature $\left(e_{*}\right.$. ., between $100^{\circ} \mathrm{C}$ and $260^{\circ} \mathrm{C}$ ) to provide conditions for steam flashing. The proportion of reactor coolant flashing to steam is then assumed equal to the proportion of radioiodines released to the atmosphere. The Midland 1 \& 2 FSAR states that $14 \%$ of the $28,000 \mathrm{~kg}$ of reactor coolant that would be released to the auxiliary building in the 13 minutes required for isolating the leak would flash to steam.

Another potential buoyant plume release from a PWR hot water line may occur after initiating the RHR system during a plant shutdown, while the water is still above $100^{\circ} \mathrm{C}$. A worst case rupture accident would occur at a complete pipe sever outside of containment, but before the line reaches the RHR pump, and immediately after the RHR system is initiated. At this time the reactor coolant is at its maximum temperature and pressure, typically ranging between $117^{\circ} \mathrm{C}$ and $138^{\circ} \mathrm{C}$ and 315 and 415 psia for the three PWR types. Applying this rupture to Trojan's (Westinghouse reactor) RHR system (using a form of Bernoulli's head loss equation and neglecting any two phase flow characteristics) would result in an instantaneous flowrate of about $2.52 \mathrm{~m}^{3} / \mathrm{s}$; with the given pressure difference between the RHR piping and the auxiliary building atmosphere (400 psia) and the size of break (0.356 $\mathrm{m}$ in diameter), the reactor coolant system would depressurize quickly. This would initiate the emergency core cooling system and operator intervention to isolate the leak. The amount 
of reactor coolant released into the auxiliary building would then depend upon how rapidly the operator could detect the problem and close the RHR isolation valves inside containment, as well as the pressure difference between the RHR piping and auxiliary building. ANSI Standard N660 "Time Response Design Criteria for Safety Related Operator Actions" March 1981, recommends minimum operator action time of six minutes for identification of problems and a single discrete manipulation (such as closing the RHR isolation valves). However, the expected response time for this type of accident is three to four minutes. Considering the range of temperatures for the three PWR types given above, about $7 \%$ to $15 \%$ of the reactor coolant released to the auxiliary building would flash to $100^{\circ} \mathrm{C}$ saturated steam with a density of $0.597 \mathrm{~kg} / \mathrm{m}^{3}$, and exit via the ventilation system through the auxiliary building stack.

\subsection{BABCOCK \& WILCOX REACTORS}

Final Safety Analysis reports from WNP 1 \& 4, Midland 1 \& 2, Arkansas 1 , Crystal River, and Oconee 1 were reviewed to evaluate potential radioactive buoyant plume releases from B\&W reactors. Information from the WNP $1 \& 4$ FSAR was used for the two cases of steam generator tube failure, with and without loss of offsite power, because the other B\&W FSARs did not contain enough data to address these releases. The information used is assumed to be applicable to other $B \& W$ reactors.

In the case with loss of offsite power, $111,600 \mathrm{~kg}$ of steam (half of which is from the affected steam generator) is assumed to be released through WNP 1 \& 4 's dump valves in an 18 minute period before the steam generator tube leak is isolated (i.e., 18 minutes after reactor trip). For this release, superheated steam exits the dump valve release vents assuming an isenthalpic expansion to one atmosphere with steam inlet conditions at $318^{\circ} \mathrm{C}$ and 1220 psia for the entire release period. During normal full power conditions, the steam leaving the steam generators is $20^{\circ} \mathrm{C}$ superheated at $308^{\circ} \mathrm{C}$ and 1060 psia. After the reactor and turbine trip, the steam pressure increases to the dump valve set point ( $1220 \mathrm{psia}$ ) and the steam temperature will rise to stay at about $20^{\circ} \mathrm{C}$ superheated conditions. This is due to the continued heat transfer from the reactor coolant to the steam generator feedwater, and from the loss of heat transfer (i.e., steam flow) from the feedwater to the turbine. Assuming the use of two dump valves upstream of the MSIVs (one for each steam generator), superheated steam would exit each release vent at the conditions shown in Table 5.1. (See Table 5.2 for data on release vent layout and set point pressures.) If all four dump valves are assumed to open instead of two, steam at $25.8 \mathrm{~kg} / \mathrm{s}$ and about $60.0 \mathrm{~m} / \mathrm{s}$ would exit each release vent.

With no loss of offsite power, superheated steam is released through the atmospheric dump valves located downstream of the MSIVs which are part of the turbine bypass system (see Figure 12). These valves are set to open between 10-15 psi lower than the upstream dump valves. It is assumed that only two of these valves will open for the 3 minute release period (one for each steam generator). The two dump valves will handle the total steam release flow at their capacities given in Table 5.2. Steam will exit these valves' release vents at 
the conditions shown in Table 5.1. Here again, the steam velocities and flow rates from each vent can vary depending upon the number of dump valves that will open. If all 16 of these downstream dump valves were assumed to open at the same time, steam at $8.8 \mathrm{~kg} / \mathrm{s}$ and $20.4 \mathrm{~m} / \mathrm{s}$ would exit each release vent. Note that $32,600 \mathrm{~kg}$ and $26,800 \mathrm{~kg}$ of reactor coolant is assumed to leak into the affected steam generator during the 18 minute and 3 minute release periods, respectively.

\subsection{WESTINGHOUSE REACTORS}

Two Westinghouse PWR nuclear power plant designs were examined: Trojan Nuclear Power Plant and Byron/Braidwood stations. In Westinghouse design plants, the turbine bypass system is capable of handling the steam load, resulting in no releases to the atmosphere if offsite power is available. Without offsite power, the secondary loop pressure will exceed the limits for the steam generator safety relief valves with the result that steam will be vented in the atmosphere. Approximately $78,000 \mathrm{~kg}$ and $83,300 \mathrm{~kg}$ of steam will be released in the 30 minute period assumed to be required to isolate the faulty steam generator in the Trojan and Byron/Braidwood plants, respectively (Portland General Electric 1973 and Commonwealth Edison Company 1978).

Westinghouse systems generally have one atmospheric dump valve and five safety relief valves upstream of the MSIVs on each of the four main steam lines. Each safety valve has two exit stacks (vents) and the dump valve has one for a total of eleven $0.36 \mathrm{~m}$ diameter release vents on each main steam line. The five safety valve set points and their rated flowrates are shown in Table 5.3. It is assumed that the safety valves set at 1185 psia, are the only safety valves needed to handle the average steam flow rate of the Trojan and Byron/Braidwood steam generators. Assuming an isenthalpic expansion to one atmosphere results in superheated steam at the conditions shown in Table 5.4 to exit each release vent in an upward direction. These flows assume

\section{TABLE 5.3. Atmospheric Dump and Safety Reljef Valve Setpoints and Rated Flow Rates for Trojan (a)}

\begin{tabular}{|c|c|c|c|c|c|}
\hline Type & \multicolumn{2}{|c|}{$\begin{array}{c}\text { Number per } \\
\text { Steam Generator }\end{array}$} & $\begin{array}{l}\text { Setpoint } \\
\text { Pressure (psia) }\end{array}$ & $\begin{array}{l}\text { Rated } \\
\text { Flowrate }\end{array}$ & $\begin{array}{c}\text { Exit Vent Radius } \\
\text { (meters) }\end{array}$ \\
\hline Dump Vaive & & 1 & & & 0.356 \\
\hline Safety Valve & & $\begin{array}{l}1 \\
1 \\
1 \\
1 \\
1\end{array}$ & $\begin{array}{l}1185 \\
1215 \\
1225 \\
1235 \\
1245\end{array}$ & $\begin{array}{r}84.6 \mathrm{~kg} / \mathrm{s} \\
86.7 \mathrm{~kg} / \mathrm{s} \\
114.9 \mathrm{~kg} / \mathrm{s} \\
115.8 \mathrm{~kg} / \mathrm{s} \\
116.8 \mathrm{~kg} / \mathrm{s}\end{array}$ & $\begin{array}{l}0.178 \\
0.178 \\
0.178 \\
0.178 \\
0.178\end{array}$ \\
\hline
\end{tabular}

(a) Trojan has 4 steam generators 
TABLE 5.4. Steam Release Conditions for Steam Generator Tube Rupture With Loss of Offsite Power For Westinghouse Reactors

\begin{tabular}{|c|c|c|}
\hline Parameter & Trojan Plant & Byron/Braidwood Stations \\
\hline Temperature & $139^{\circ} \mathrm{C}$ & $130^{\circ} \mathrm{C}$ \\
\hline Velocity & $102 \mathrm{~m} / \mathrm{s}$ & $111 \mathrm{~m} / \mathrm{s}$ \\
\hline Density & $0.537 \mathrm{~kg} / \mathrm{m}^{3}$ & $0.537 \mathrm{~kg} / \mathrm{m}^{3}$ \\
\hline Exit radius & $0.178 \mathrm{~m}$ & $0.178 \mathrm{~m}$ \\
\hline Flow rate & $\begin{array}{l}5.41 \mathrm{~kg} / \mathrm{s} \text { through each } \\
\text { vent }\end{array}$ & $5.93 \mathrm{~kg} / \mathrm{s}$ through each vent \\
\hline Release time & 30 minutes & 30 minutes \\
\hline Release Vents & 8 & 8 \\
\hline $\begin{array}{l}\text { Height of release } \\
\text { point }\end{array}$ & 3D. $5 \mathrm{~m}$ above grade & - \\
\hline $\begin{array}{l}\text { a saturated steam } \\
\text { relief valve presst } \\
\text { steam at } 1050 \text { psia } \\
\text { set point, due to } \\
\text { increase to stay at }\end{array}$ & $\begin{array}{l}\text { temperature of } 296^{\circ} \mathrm{C} \text { in th } \\
\text { are of } 1185 \text { psia. Normal } \\
\text { and } 287^{\circ} \mathrm{C} \text {. As the pressu } \\
\text { the reactor/turbine trip, } \\
\text { t saturated steam conditic }\end{array}$ & $\begin{array}{l}\text { steam generator at the safety } \\
\text { erating conditions are saturated } \\
\text { increases to the safety valve } \\
\text { steam temperature will also } \\
\text { - }\end{array}$ \\
\hline
\end{tabular}

\subsection{COMBUSTION ENGINEERING (CE) REACTORS}

The Combustion Engineering Standardized Safety Analysis Report (CESSAR) FSAR and the Palo Verde FSAR were reviewed to characterize potential buoyant plume releases from CE reactors. The Palo Verde FSAR was used for exit vent sizes, generic safety valve set points, and the temperature and pressure of the steam generators during normal operating conditions. Information on the amount and time period of steam releases was. taken from the CESSAR FSAR. The CE plants' basic operational characteristics and component performance following a steam generator tube rupture with a reactor trip are similar to those of the Westinghouse and B\&W designed plants. Differences are found in the number and size of exit vents, release times, temperature of vented steam, etc. For a CE plant, the safety relief valve layout is similar to the Trojan Plant having one atmospheric dump valve and five safety valves for each of the four main steam lines. The safety valves on each main steam line are arranged in three banks, with set points and capacities shown in Table 5.5 . 
According to the CESSAR FSAR, with a loss of offsite power, $49,700 \mathrm{~kg}$ of steam may be released in an 8.73 minute period before the affected steam generator is isolated. The main steam safety valves open at 1282 psia and after 8.73 minutes close at 1218 psia. The maximum steam generator pressure achieved during this release period is 1310 psia which occurs 8 seconds after the safety valves first open. Though the number of safety valves that vent during this release period is not stated in the FSARs, it is assumed that one valve on each main steam line will open. This is based on the discussion in section 5.0 concerning safety valve set point error and the minimum capacity of the safety valves. However, the analysis did state that a peak pressure of 1310 psia was achieved during the 8.73 minute release period. At this pressure, all or none of the 4 safety valves with set points at 1305 psia may open considering a $\pm 1 \%$ set point error. If all 4 of these valves did open it would be for a small fraction of the release period.

Assuming steam generator saturation conditions at $302^{\circ} \mathrm{C}$ and $1282 \mathrm{psia}$ (normal operating conditions are at $1020 \mathrm{psia}$ and $285^{\circ} \mathrm{C}$ ) and an isenthalpic expansion to one atmosphere through the safety valve release vents, superheated steam will exit each valve vent at the conditions shown in Table 5.6. During the release period, $36,500 \mathrm{~kg}$ of reactor coolant will leak to the affected steam generator.

With no loss of offsite power, a total of $6,000 \mathrm{~kg}$ of steam is released to the environinent in a 107 second release period (Combustion Engineering, Inc. 1979). The main steam safety valves open and close at 1282 psia and 1218 psia, respectively. The maximum steam generator pressure reached is 1283 psia. As with the loss of offsite power case, four safety valves are assumed to open, one on each main steam line. This results in superheated steam exiting each release vent at the the conditions shown in Table 5.6 .

TABLE 5.5 Atmospheric Dump and Safety Relief Valve Setpoints and Rated Flowrates For Palo Verde $(a)$

\begin{tabular}{|c|c|c|c|c|}
\hline Type & $\begin{array}{c}\text { Number per } \\
\text { Steam Generator }\end{array}$ & $\begin{array}{l}\text { Setpoint } \\
\text { Pressure (psia) }\end{array}$ & $\begin{array}{l}\text { Rated }(b) \\
\text { Flowrate } \\
\end{array}$ & $\begin{array}{c}\text { Exit Vent } \\
\text { Radius (meters) } \\
\end{array}$ \\
\hline $\begin{array}{l}\text { Dump Valve } \\
\text { Safety Valve }\end{array}$ & $\begin{array}{l}-- \\
2 \\
2 \\
6\end{array}$ & $\begin{array}{l}- \\
1250 \\
1305 \\
1330\end{array}$ & & $\begin{array}{l}-- \\
0.305 \\
0.305 \\
0.305\end{array}$ \\
\hline
\end{tabular}

(a) Palo Verde has 2 Steam Generators

(b) The ininimum rated flowrate of all safety valves (10 per steam generator, i.e., 5 per main steam line) is $2,395 \mathrm{~kg} / \mathrm{s}$. 
TABLE 5.6. Steam Release Conditions for a Combustion Engineering Reactor Steam Generator Tube Rupture With and Without offsite Power

$\begin{array}{llll}\text { Parameters } & \text { With Loss of Offsite Power } & & \text { With No Loss of Offsite Power } \\ \text { Temperature } & 132^{\circ} \mathrm{C} & & 132^{\circ} \mathrm{C} \\ \text { Velocity } & 4 \text { vents } 0149 \mathrm{~m} / \mathrm{s} & 4 \text { vents } 087.8 \mathrm{~m} / \mathrm{s} \\ \text { Density } & 0.548 \mathrm{~kg} / \mathrm{m}^{3} & 0.548 \mathrm{~kg} / \mathrm{m}^{3} \\ \text { Exit radius } & 4 \text { vents } 0.305 \mathrm{~m} & 4 \text { vents } 00.305 \mathrm{~m} \\ \text { Flow rate } & 23.7 \mathrm{~kg} / \mathrm{s} \text { through each vent } & 14.0 \mathrm{~kg} / \mathrm{s} \text { through each vent } \\ \text { Release time } & 8.73 \mathrm{~min} . & 1.783 \mathrm{~min} \text {. (107 seconds) }\end{array}$




\subsection{EVALUATION OF POTENTIAL RELEASES}

The last two sections have discussed potentially buoyant releases from boiling water and pressurized water reactors in detail. Numerous examples of steam and high temperature water flows were listed. In this section, the consequences of breaks in these lines will be examined in terms of the potential behavior of the released water or steam. The next two sub-sections summarize typical releases from BWRs and PWRs and discuss a number of factors related to the releases that affect the atmospheric behavior of the releases. The following sub-section discusses the atmospheric behavior of the typical releases, and the final sub-section discusses the releases related to the steam generator tube rupture at the Ginna Nuclear Power Plant that occurred January 25, 1982. The discussion of the Ginna releases demonstrates the application of the techniques discussed in Section 3 and illustrates several potential short-comings that can arise if the methods outlined in Section 3 are applied without question.

\subsection{BWR RELEASES}

BWR releases associated with main steam line breaks, residual heat removal line breaks and high pressure core insertion line breaks have the greatest likelihood of being buoyant. Table 6.1 summarizes typical durations and temperatures for these releases. Releases through the condenser air ejector are not included in the list because they are not likely to be buoyant. Their lack of buoyancy is due to the small volume and low temperature of the water vapor released and the various filters and delays included in the path between the air ejector and the atmosphere.

Main steam line breaks present a significant threat to the reactor. As a result, the reactor is protected by valves that close automatically in the event of loss of pressure in the main steam line. The time between a loss of pressure, assumed to be associated with a steam line break, and valve closure is listed in Table 6.1 under duration. In the interim between the steam line break and valve closure, two distinct release modes occur. Initially, the release consists of superheated steam. Shortly after the break, the decrease in pressure permits the water level in the reactor to rise and the release changes to a steam-water mixture. This change is reflected in the table by the two release durations and temperatures for each of the containment systems. The steam-water mixture in the second phase of the release is approximately $37 \%$ steam by mass, but by volume it is about $99.9 \%$ steam. As a result, much of the water will be carried away from the break by the steam.

The path between the actual release point and the atmosphere depends on the location of the steam line break and the plant design. In general, in the event of a massive break, the path will be through a side of one of the buildings in the reactor building complex. In some BWRs blowout panels are provided to accommodate the over-pressures associated with these releases. Table 6.1 gives the volume flux parameters that could be associated with main steam ine 
TABLE 6.1. Typical Release Characteristics for Potentially Buoyant Plumes from Boiling Water Reactors

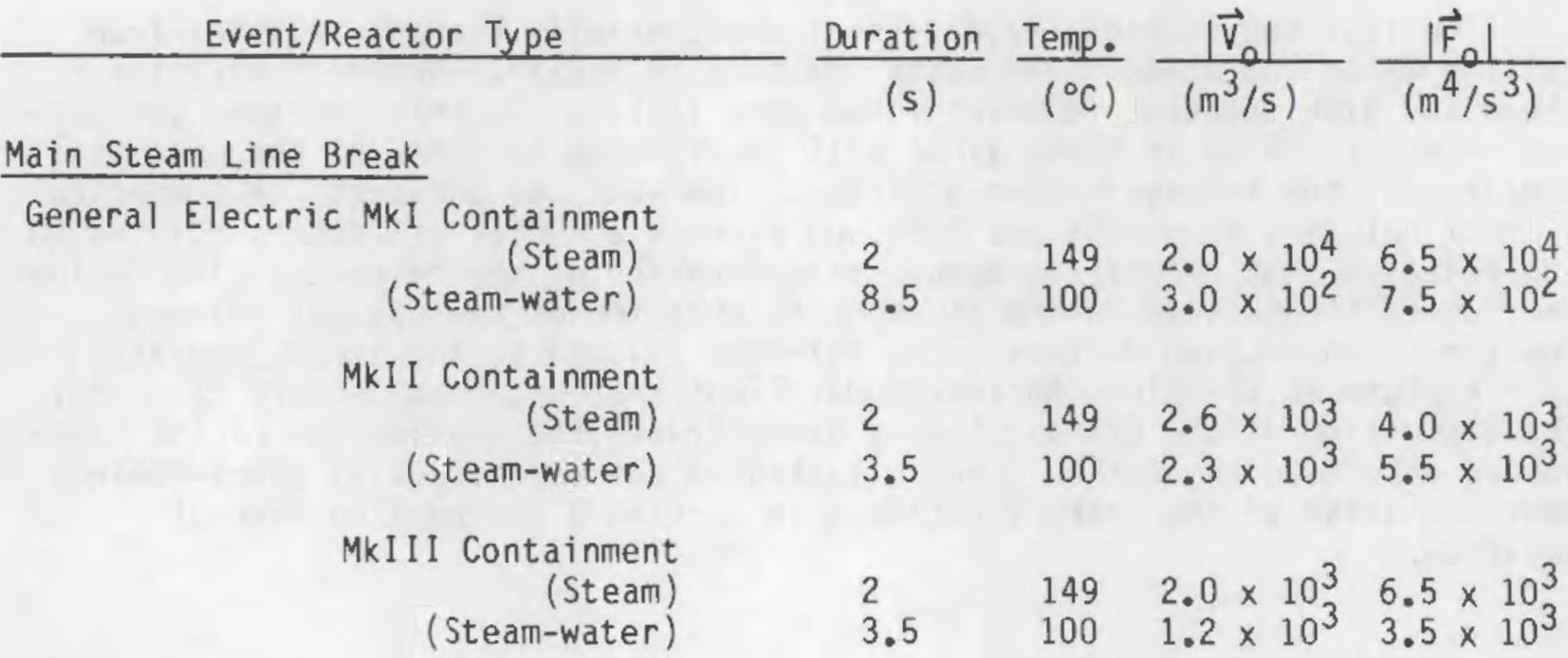

Residual Heat Removal Line Break

General Electric MK II Containment

30

$1492.5 \times 10^{2} 8.0 \times 10^{2}$

High Pressure Core Injection Line Break

General Electric MkII Containment

Penetration Room

30

Pump Room
30
149

149
$8.4 \times 10^{1} 2.8 \times 10^{2}$

$2.0 \times 10^{2} 6.5 \times 10^{2}$

breaks. These fluxes are likely to be horizontal. Therefore, it is anticipated that the momentum fluxes will be horizontal and not contribute to plume rise. However, the high temperature and low density of the releases, compared to ambient air, result in a significant buoyant flux.

The potential buoyancy fluxes expected to be associated with BWR main steam line breaks are listed in the last column of Table 6.1 . The actual buoyancy fluxes of main steam line break releases when the atmosphere is reached may be less than the tabled values as a result of the path taken to the atmosphere. The values of the flux parameters are also functions of the ambient temperature and humidity, but the variations due to the ambient atmospheric conditions amount to only a few percent. These variations have been neglected because of the large uncertainty associated with the change in the buoyancy flux parameter between the source and the atmosphere.

8 reaks in the residual heat removal and high pressure core insertion lines do not pose as serious a threat to the reactor as does a break in the main steam line. Therefore, in the event of a break in one of these lines, the time 
required to take action to stop the release of effluents may be longer than with a main stean line break. Table 4.4 indicates that the release duration may be 30 to 60 seconds; a duration of 30 seconds is assumed in Table 6.1 to maximize the release rate.

The effluent released following a break in either a residual heat removal or high pressure core insertion line would be superheated steam from isenthalpic expansion of saturated water at high temperature and pressure. The volume of steam released in either case could be large enough to result in sufficient over-pressure within the reactor building, steam tunnel or turbine building to activate blowout panels or vent through the sides of the building. In this respect, the effluents would behave similarly to those from a main steam line break. Typical volume and buoyancy flux parameters that might be associated with breaks of these lines are given in Table 6.1.

In the event that a leak in a main steam line, residual heat removal line, or a high pressure core injection line does not give sufficient flow to activate blowout panels or vent through the side of a building, the effluents can be expected to mix with the air in the buildings and be exhausted through the building heating and ventilation system. In this case, the path to the atmosphere would likely result in a significant reduction in the buoyancy flux parameter as the effluent is held up and mixed.

\subsection{PWR RELEASES}

Of the potential breaks in steam and hot water lines in PWRs, two were identified as having the potential to result in buoyant plumes. These breaks are a steam generator tube rupture and a break in the residual heat removal line. In the case of a steam generator tube rupture, a buoyant plume will result if a pressure relief valve opens. Steam generator tube ruptures at four operating nuclear power plants in the United States have been analyzed (USNRC 1980 and 1982). In three of the four events the reactors were brought to a shutdown condition without a direct release of radioactive material to the environment through relief or safety valves. The fourth case was Ginna. Thus, although releases may occur through relief and safety valves following a steam generator tube rupture, the rupture does not necessarily result in a buoyant. release. On the other hand, failure of a residual heat removal line is likely to result in a release to the atmosphere that is similar to the release following a residual heat return line break in a BWR. Table 6.2 gives characteristics likely to be associated with potentially buoyant releases froin PWRs.

Releases of radioactive effluents are likely from several events that are not likely to produce buoyant plumes. One of these is through the condenser air ejector following a steam generator tube rupture. The volume flow and temperature of the air ejector off-gases are too low to give a byoyant plume when they reach the atmosphere. Typical flows are less than $0.5 \mathrm{~m} / \mathrm{s}$, and these are generally mixed with air prior to being exhausted to the atmosphere. Another 
TABLE 6.?. Typical Release Characteristics for Potentially

Buoyant Plumes for Pressurized Water Reactors

Pressurized Water Reactors

\section{Event/Reactor Type
Steam Generator Tube Rupture}

(Safety and Dump Valves, per valve)

Babcock and Wilcox

with offsite power

without offsite power

Westinghouse

Combustion Engineering

with offsite power

without offsite power
Duration

(s)
Temp.

$\left({ }^{\circ} \mathrm{C}\right)$

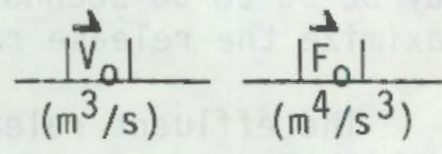

Residual Heat Removal Line Break

Babcock and Wilcox

$\begin{array}{rrrr}180 & 187 & 150 & 5.8 \times 10^{2} \\ 1080 & 187 & 110 & 4.2 \times 10^{2} \\ 1800 & 139 & 78 & 2.3 \times 10^{2} \\ & & & \\ 520 & 132 & 43 & 1.4 \times 10^{2} \\ 110 & 132 & 26 & 8.0 \times 10^{1}\end{array}$

$100280 \quad 7 \times 10^{2}$

potential source of buoyant plumes considered and rejected is a break in the letdown line. Again, the flow volume is too low to be a source of significant buoyancy.

Evaluation of the potential releases from pressure relief valves on PWRs is straightforward compared with the evaluation of releases following BWR main steam line breaks because the path from the valve to the atmosphere is well defined. One or more vent lines are associated with each valve. These lines guide the effluent directly to the atmosphere and prevent dilution of the effluent prior to its being exhausted to the atmosphere. As a result, the volume and buoyancy flux parameters estimated for the release to the atmosphere are essentially the parameters estimated for the valve divided by the number of vents per valve. For example, Babcock and Wilcox plants have a single vent for each valve. Therefore, the volume and buoyancy flux parameters used for estimating plume rise may be determined directly from volume and buoyancy flux parameters computed for flow away from the valve. On the other hand, Westinghouse reactors have two vents for each valve, and the fluxes from the vents are, therefore, one half the fluxes from the valve. The fluxes given in Table 6.2 are on a per vent basis.

The duration of releases from PWR relief valves are not well defined because the valves, particularly safety valves, will open intermittently in response to the pressure buildup in the secondary steam lines. The times listed in the duration column of Table 6.2 should be interpreted as periods of 
potential vulnerability to releases rather than actual release durations. Actual release durations should be shorter than the periods given. Perhaps a duration of 30 to 60 seconds might be appropriate for each valve opening, assuming normal valve operation. In the absence of more definitive information, on actual release times, the flux parameters in Table 6.2 have been estimated from rated flow through valves assuming a constant flow rate.

\subsection{ATMOSPHERIC BEHAVIOR}

The values of the buoyancy flux parameter for the releases of concern listed in Tables 6.1 and 6.2 range from less than 100 to more than $10,000 \mathrm{~m}^{4} / \mathrm{s}^{3}$. This sub-section examines the effects of buoyancy flux parameters in this range on plume rise as a function of wind speed and atmospheric stability. Both initial and final plume rise are considered. Tables 6.1 and 6.2 also indicate that both superheated and saturated steam releases are possible. The near release point behavior of the two types of steam is examined as a function of ambient temperature and humidity and distance from the release point.

Near the release point, the rise of buoyant plumes is primarily a function of the buoyancy flux parameter and wind speed. The relationship is given in (3.5). Figure 6.1 shows the plume rise expected at a distance of $100 \mathrm{~m}$ from the source as a function of $F_{0}$ and wind speed. For 10 wind speeds $(1 \mathrm{~m} / \mathrm{s})$ and very stable atmospheric conditions, final plume rise is attained in less than $100 \mathrm{~m}$ downwind distance. Therefore, plume rise for $1 \mathrm{~m} / \mathrm{s}$ and $E$ and $F$ stability classes is shown separately from plume rise for A through E stabilities with a wind speed of $1 \mathrm{~m} / \mathrm{s}$. As indicated by (3.5), the plume rise range, given a 3 -order of magnitude variation in buoyancy flux and an order of magnitude variation in wind speed range, is two orders of magnitude. Wind speed changes give larger changes in plume rise at a distance of $100 \mathrm{~m}$ than do changes in buoyancy flux parameter.

The plume radius at $100 \mathrm{~m}$ downwind is shown in Figure 6.2. Again, the radius is primarily a function of buoyancy parameter and wind speed, with stability assuming a significant role at low wind speeds in stable atmospheres. Plume radius in Figure 6.2 is estimated from (3.4) with the travel distance, d, defined by analogy with (3.17) used in place of the plume rise. Plume radius is clearly only a slowly increasing function of buoyancy parameter, and for high wind speed it is almost independent of the buoyancy parameter.

Farther downwind, plume rise is, more generally, a function of buoyancy, wind speed and stability. Figure 6.3 shows the final plume rise for Class $F$ atmospheric stability for reasonable wind speeds and a wide range of buoyancy flux parameter values. For neutral and unstable atmospheric conditions, other variables, such as surface roughness and surface heat flux become important. Plume rise estimated by (3.14) should be larger than that estimated for stable conditions using (3.12), and plume rise for unstable atmospheric conditions 


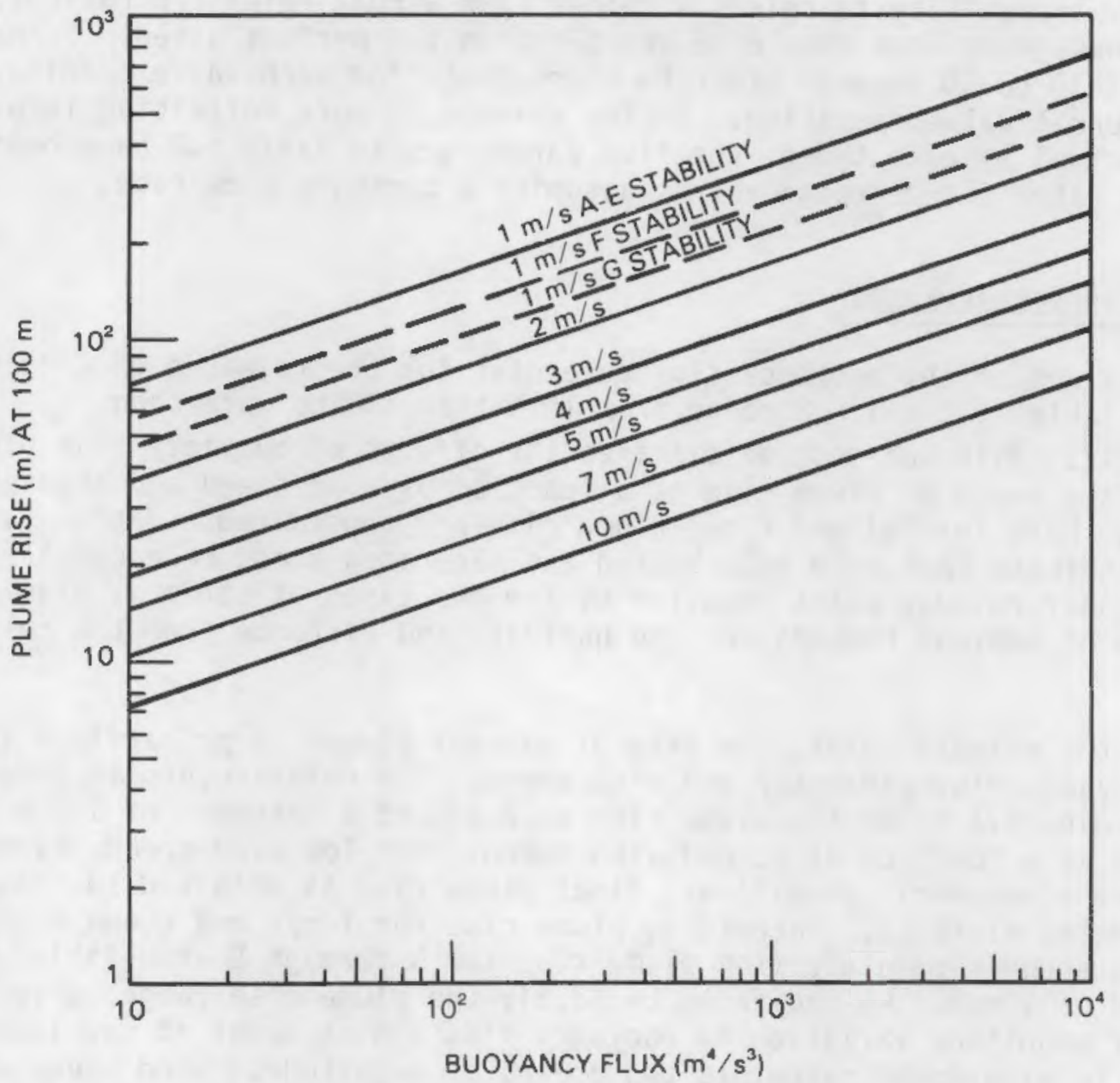

FIGURE 6.1. Plume Rise at $100 \mathrm{~m}$ as a Function of Buoyancy Parameter, Wind Speed and Stability

should be even larger. Therefore, the use of (3.12) with $E$ stability should provide conservative estimates of ground-level concentrations in neutral and unstable conditions.

The distance to final plume rise in stable atmospheric conditions is also a function of wind speed and stability. Figure 6.4 gives estimates of this distance. It is reasonable to assume that the distance to final plume rise for neutral and unstable conditions, if such a distance is meaningful, is larger than is shown for stability Class $E$.

The distances determined from Figure 6.4 can be used, along with the plume rise estimates to estimate the travel distance between the release point and the level-off point using (3.17) and the plume radius using (3.4). As the plume rise or distance to final rise increases, some judginent needs to be 


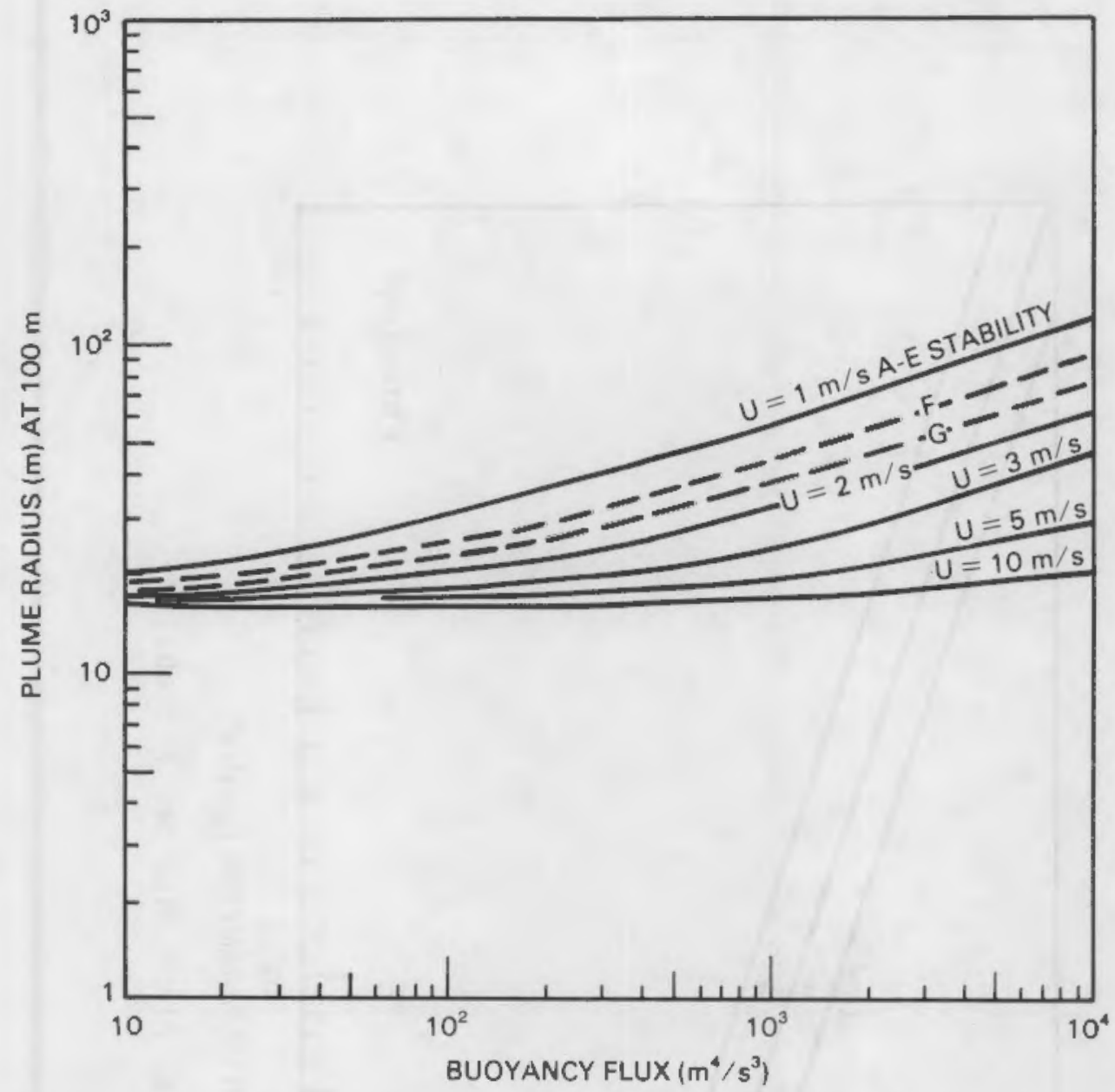

FIGURE 6.2. Plume Radius at $100 \mathrm{~m}$ as a Function of Buoyancy Source

applied to the estimates of plume radius. The effects of atmospheric turbulence become important as the distance from the release point increases. Therefore, when the plume approaches its final rise asympotically, as during periods of high wind speeds, it may be appropriate to assume final rise at a somewhat shorter distance than indicated by (3.17). In estimating final plume rise, it is also important to consider the depth of the atmospheric mixing layer. In some cases, the ultimate rise of buoyant plumes may be limited by the stability at the top of the mixing layer rather than by the stability within the mixing layer. In these cases the surface layer characterization of the atmosphere used in the equations in Section 3 will overestimate the plume rise. When the equations of Section 3 give plume rise estimates that are greater than the mixing layer depth, the mixing layer depth will provide a conservative estimate of the plume rise.

After plume rise has been estimated, two checks can be made to evaluate the estimates. The first check is to compare the plume rise estimate with the height of the reactor complex building wake at some nominal distance downind. 


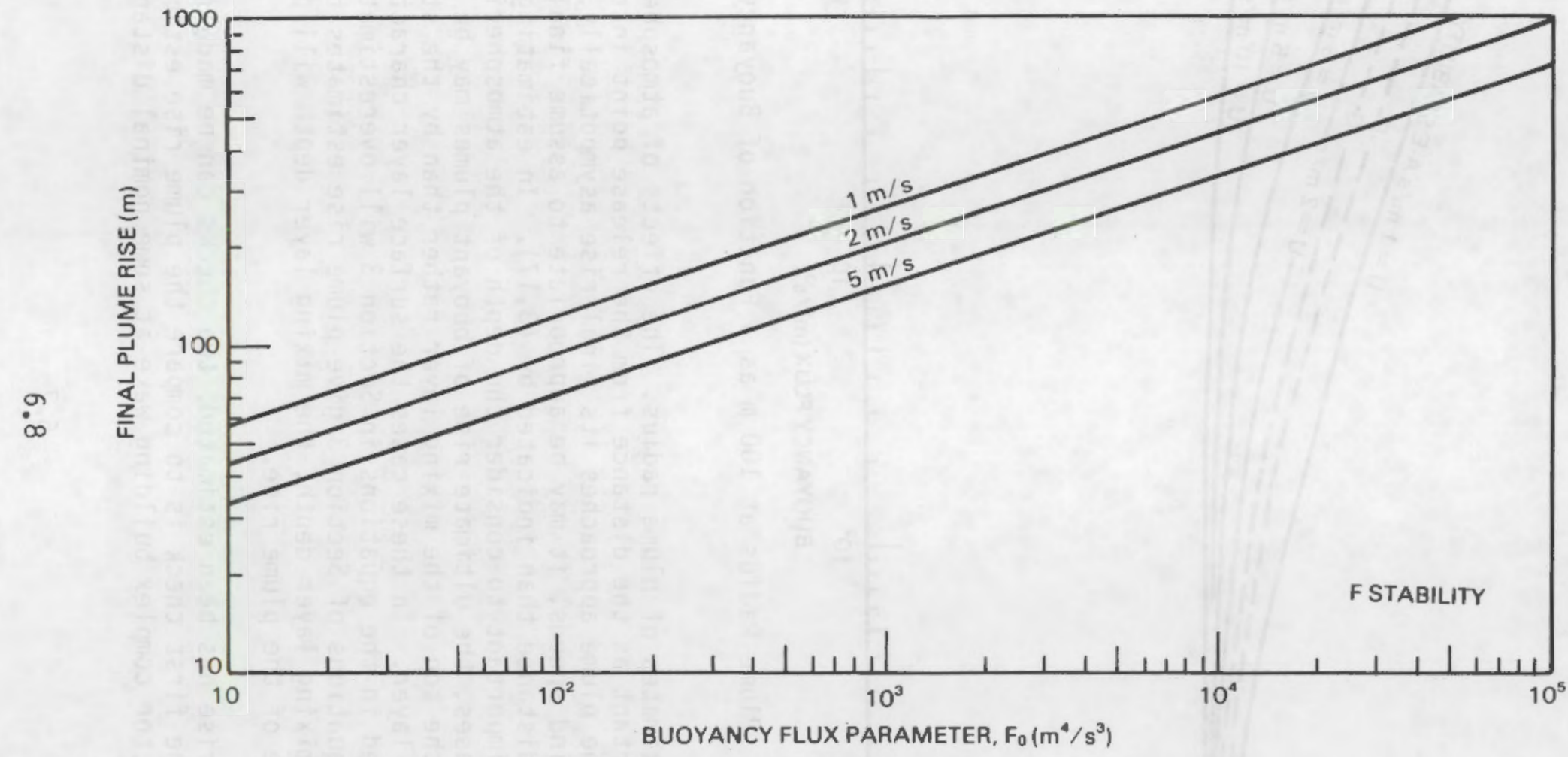

FIGURE 6.3. Final Plume Rise for F Stability 


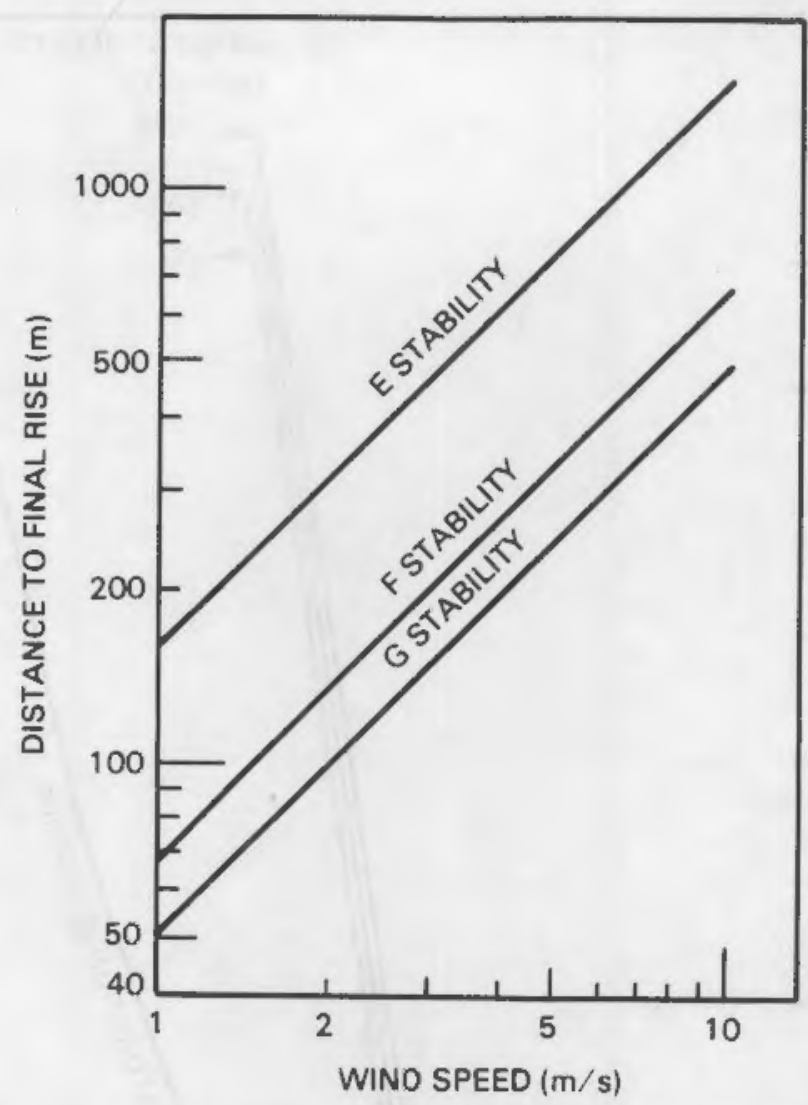

FIGURE 6.4. Distance to Final Plume Rise for Stable Atmospheric Conditions

A distance of $100 \mathrm{~m}$ seens to be reasonable. If the rise, minus the plume radius, is greater than the height of the wake, then the plume is likely to have escaped the building wake. The second check is to compare the plume radius at level-off (final plume rise distance) with the effective release height. For internal consistency of the models at that point, the ratio of the effective release height to the plume radius should be greater than or equal to 1.0. When this condition is met, the Gaussian plume model will give a groundlevel concentration that is equal to or greater than the concentration for a corresponding position relative to the axis of a top-hat plume. If the condition is not met, it would be appropriate to determine the distance at which the effective release height equals the plume radius due to initial expansion, assume that the plume levels-off at this point, and set sigma equal to onethird the effective release height. The ratio between the effective release height and the plume radius at level-off will be less than with only in the case of low-level, low buoyancy releases in high wind speeds.

The temperature and specific humidity in the near field plume from a $100^{\circ} \mathrm{C}$ release into $15^{\circ} \mathrm{C}$ atmospheric conditions is shown in Figure 6.5 for ambient relative humidities of 0,50 and $100 \%$. Clearly the degree of supersaturation near the release point is not highly dependent on the ambient conditions, but 


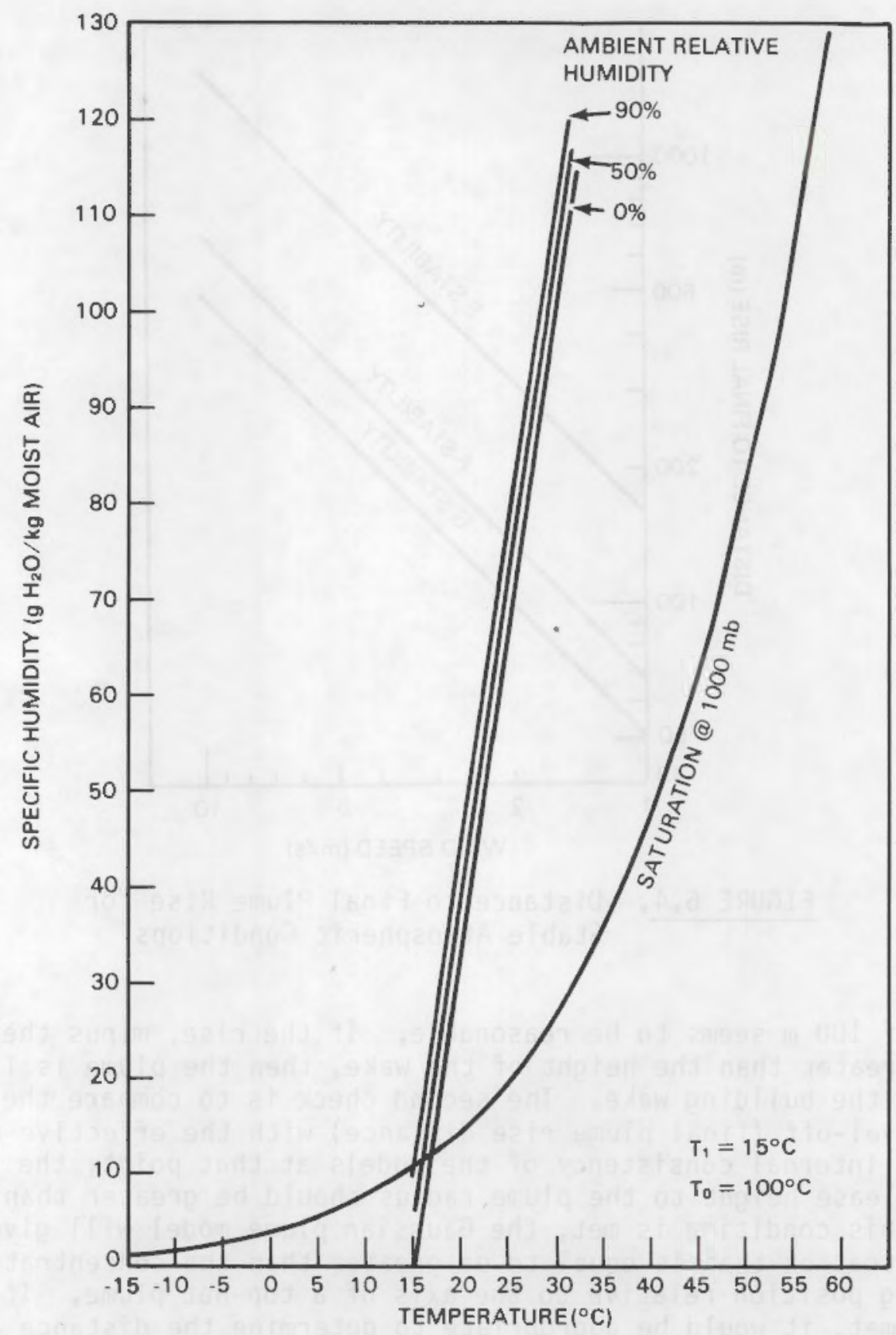

FIGURE 6.5. Decrease of Specific Humidity and Temperature in the Near Field Plume from $100^{\circ} \mathrm{C}$ Steam Release in a $15^{\circ} \mathrm{C}$ Atmosphere 
the ambient conditions beci) le important as the plume becomes diluted. Figures for different atmospheric and release conditions show similar features. As the ambient temperature decreases, the effects of changing the ambient relative humidity decrease.

Although Figure 6.5 clearly indicates that the near field will be supersaturated, it does not provide a clear indication of the extent of the supersaturated conditions. Figures 6.6 and 6.7 provide better indications of the

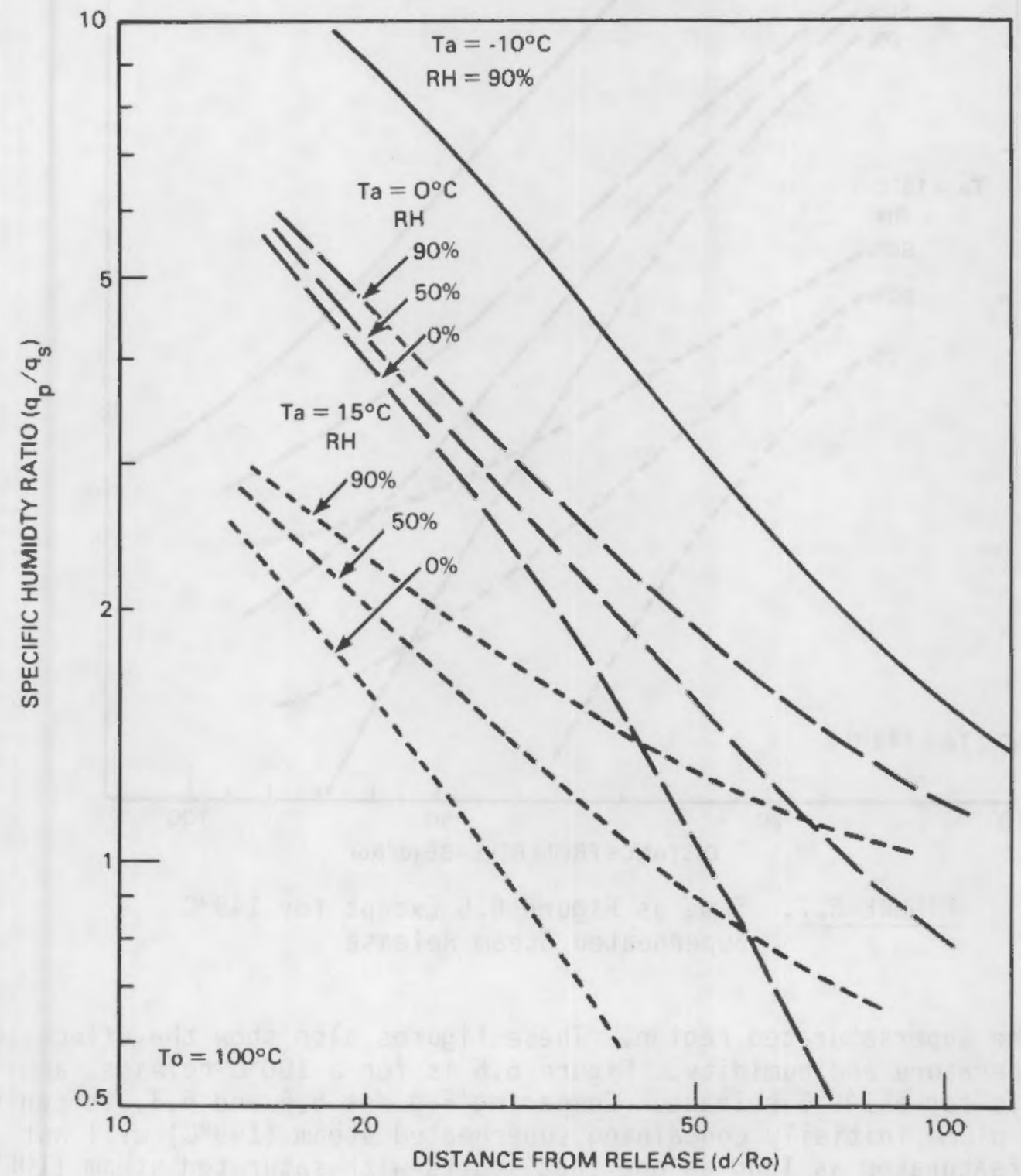

FIGURE 6.6. Decrease in Specific Humidity in the Near Field Plume of a $100^{\circ} \mathrm{C}$ Saturated Steam Release as a Function of Distance from the Source 


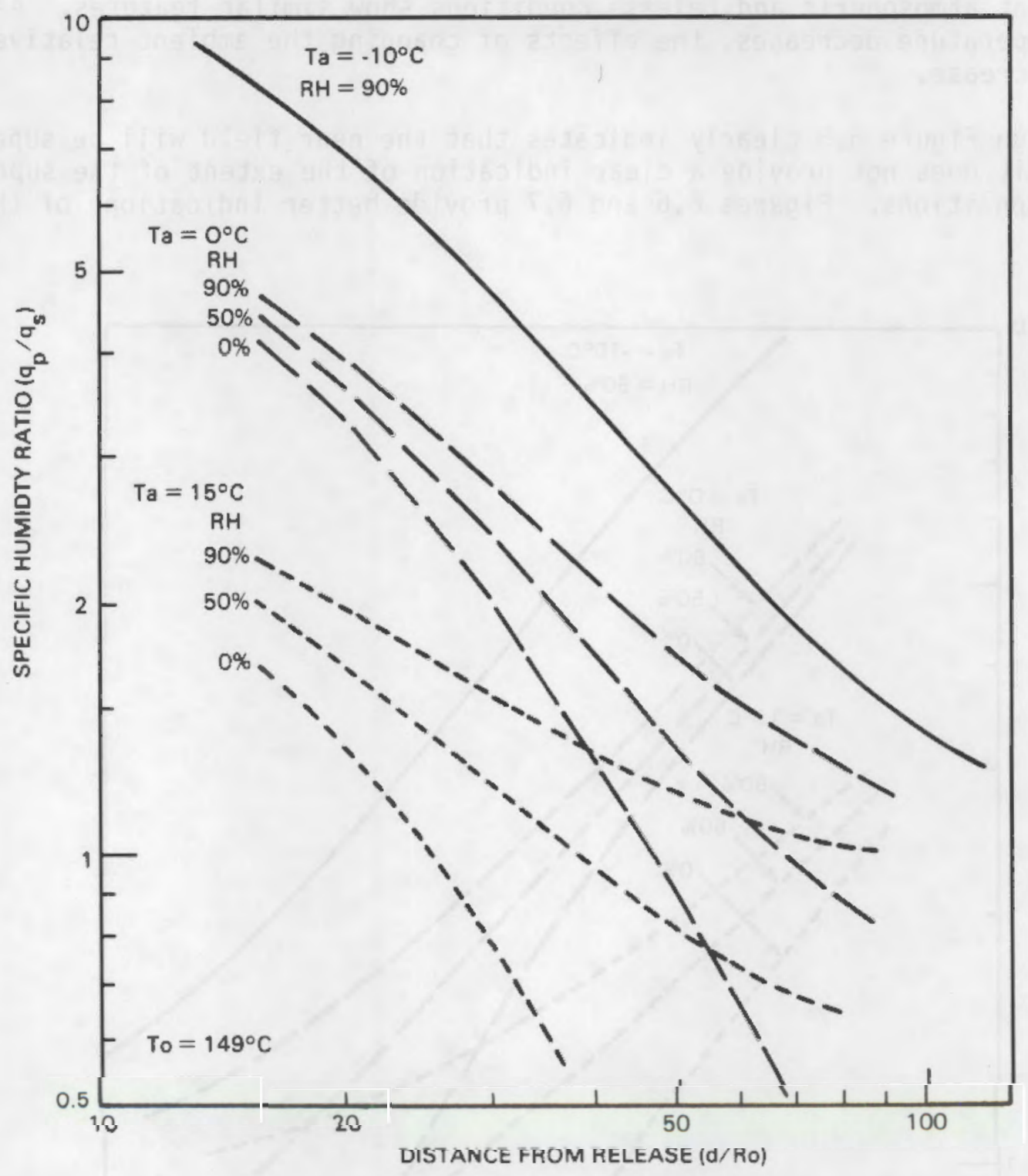

FIGURE 6.7. Same as Figure 6.6 Except for $149^{\circ} \mathrm{C}$ Superheated Steam Release

extent of the supersaturated region. These figures also show the effects of ambient temperature and humidity. Figure 6.6 is for a $100^{\circ} \mathrm{C}$ release, and Figure 6.7 is for a $149^{\circ} \mathrm{C}$ release. Comparing Figures 6.6 and 6.7 , it can be seen that a plume initially containing superheated steam $\left(149^{\circ} \mathrm{C}\right)$ will not remain supersaturated as long as one that starts with saturated steam $\left(100^{\circ} \mathrm{C}\right)$. 


\subsection{EVALUATION OF THE GINNA RELEASES}

At about 9:25 a.m. on January 25, 1982, one of the steam generator tubes ruptured in the $B$ steam generator of the R. F. Ginna Nuclear Power Plant. The events pertaining to the rupture are fully documented in NUREG-0909 (USNRC 1982). This subsection demonstrates application of the methods for estimating the atmospheric behavior of potentially buoyant effluents using the information contained in the Ginna report.

The Ginna power plant is located on the south shore of Lake Ontario. At the time of the generator tube rupture, and for the entire period of interest, there was onshore flow from the northwest at about $6 \mathrm{~m} / \mathrm{s}$ at a height of $10 \mathrm{~m}$. The atmospheric stability was neutral, the temperature was about $-12^{\circ} \mathrm{C}$, and light snow was falling.

One of the early indications of the generator tube rupture was an air ejector radiation monitor alarm. As has been discussed, a release through the air ejector is nonbuoyant. There were also releases through power operated relief valves and a safety valve on the main steam line between the $B$ steam generator and the turbine. Of these releases, those through the safety valve were most significant.

The safety valve opened five times during the course of the accident. The first two openings occurred about an hour after the tube rupture. During these openings, steam was vented to the atmosphere until pressure dropped below the valve set point. There may have been some steam leakage through the valve after the first opening. Between 10:38 and 11:21 a.m., the safety valve opened two more times. In both of these cases, there was a two phase flow of water and steam through the valve. Finally, the valve opened a fifth time at about 11:37 a.m. This time the valve is suspected of discharging liquid rather than steam, and is believed to have failed to properly seat when it closed.

Early Superheated Steam Releases. Each of the main steam lines at the Ginna plant has four safety valves. The values have a rated flow of $103.3 \mathrm{~kg} / \mathrm{s}$ at $1100 \mathrm{psig.} \mathrm{One} \mathrm{of} \mathrm{the} \mathrm{four} \mathrm{valves} \mathrm{on} \mathrm{each} \mathrm{line} \mathrm{has} \mathrm{an} \mathrm{opening} \mathrm{set} \mathrm{point} \mathrm{at}$ $1085 \mathrm{psig}$, and the other three have $1140 \mathrm{psig}$ set points. It is assumed that a single valve opened and that flow occurred through the valve at the rated value until the pressure in the line dropped below the closing set point. The temperature of the steam in the 1 ine is assumed to be $285^{\circ} \mathrm{C}$. Each safety valve exhausts into two $0.178 \mathrm{~m}$ diameter vent lines and then directly to the atmosphere. It is assumed that the vents are vertical and uncapped.

The safety valve and vent act together as throttle. Isenthalpic expansion of $285^{\circ} \mathrm{C}$ steam at $1085 \mathrm{psig}$ to atmospheric pressure at about $-10^{\circ} \mathrm{C}$ gives an effluent of superheated steam at $149^{\circ} \mathrm{C}$ and a density of $0.525 \mathrm{~kg} / \mathrm{m}^{3}$. The initial volume flow rate in the atmosphere is $98.4 \mathrm{~m}^{3} / \mathrm{s}$, the volume flux parameter is $31.3 \mathrm{~m}^{3} / \mathrm{s}$, and the buoyancy flux parameter is $115.6 \mathrm{~m}^{4} / \mathrm{s}^{3}$. Figures 6.1 and 6.2 show that for a buoyancy flux parameter of $115.6 \mathrm{~m}^{4} / \mathrm{s}^{3}$ and a wind speed of $8 \mathrm{~m} / \mathrm{s}$, the expected plume rise and radius at a downwind distance of $100 \mathrm{~m}$ are about 21 and $16 \mathrm{~m}$, respectively. The release height is assumed to be about 
$20 \mathrm{~m}$ and the wind speed at release height is assumed to be about $8 \mathrm{~m} / \mathrm{s}$. Comparing the base of the plume at $100 \mathrm{~m}$ with the top of the building wake leads to the conclusion that the plume is entrained in the building wake. However, the initial plume momentum has been neglected.

If the $285^{\circ} \mathrm{C}$ steam is assumed to be throttled to atmospheric pressure across the safety valve, the flow in the vents must be about $991 \mathrm{~m} / \mathrm{s}$. This velocity is unrealistically high. Flow in the vents is more likely to be sonic $(330 \mathrm{~m} / \mathrm{s})$, with sufficient pressure being maintained in the vents to conserve the mass flow rate by increasing the density of the steam. If momentum is conserved in the initial expansion of the steam from the yent to atmospheric pressure, the plume's initial momentum flux is about $10^{4} \mathrm{~m}^{4} / \mathrm{s}^{2}$. According to Hanna et al. 1982, momentum should dominate the initial plume rise for the first $|\vec{M}| /\left|\vec{F}_{0}\right|$ seconds of rise. In this case momentum should dominate plume rise for about 90 seconds. The plume rise due to momentum alone in the first $100 \mathrm{~m}$ downwind will be about $52 \mathrm{~m}$. Therefore, the plume should clear the building wake.

Equations (3.14) and (3.16) give estimates of the final plume rise and final plume rise distance assuming that the ultimate rise is determined by buoyancy rather than momentum. The estimated rise is about $440 \mathrm{~m}$. The rise estimated for a momentum-dominated plume would be about $75 \mathrm{~m}$. Therefore it is reasonable to neglect momentum in the final plume rise computation. The distance to the level-off point is estimated to be about $9500 \mathrm{~m}$. This estimate poses somewhat of a problem because at this distance the plume radius would be about $1500 \mathrm{~m}$ assuming that (3.4) could be applied to level-off. Clearly the use of the entrainment model for plume travel distances of this magnitude is inappropriate. A workable alternative is to assume the entrainment model that leads to (3.4) for only the first $100 \mathrm{~m}$ and to assume that Gaussian diffusion is dominant beyond $100 \mathrm{~m}$.

Figure 6.8 shows the estimated ground-level air concentrations normalized to the release rate for atmospheric conditions existing at the time of the Ginna steam generator tube rupture for several effective release heights. The ground-level release curve $\left(h_{e}=0\right)$ is appropriate for surface releases and releases that do not escape the building wake. It gives an upper limit to the time-integrated air concentration estimates. The three remaining curves correspond to alternative choices for releases that escape the building wake. The curve marked $n_{0}=72 \mathrm{~m}$ corresponds to assuming that the plume from the early superheated steam releases levels-off at $100 \mathrm{~m}$ downwind. The curve marked $h_{e}=$ $95 \mathrm{~m}$ assumed that the final plume rise is equal to the rise estimated for a non-buoyant, momentum driven plume, and the curve marked $460 \mathrm{~m}$ assumes that the plume rises to full height estimated for a buoyant plume. These estimates do not take into account any effects that may be related to precipitation falling during the period of release.

If it is assumed that the moisture in the plume does not enhance washout, a first-order decay model can be used to estimate the surface deposition under the plume. Models of this sort are discussed by Hanna et al. (1982) and in Slade (1968). Figure 6.9 shows normalized surface concentrations under the 


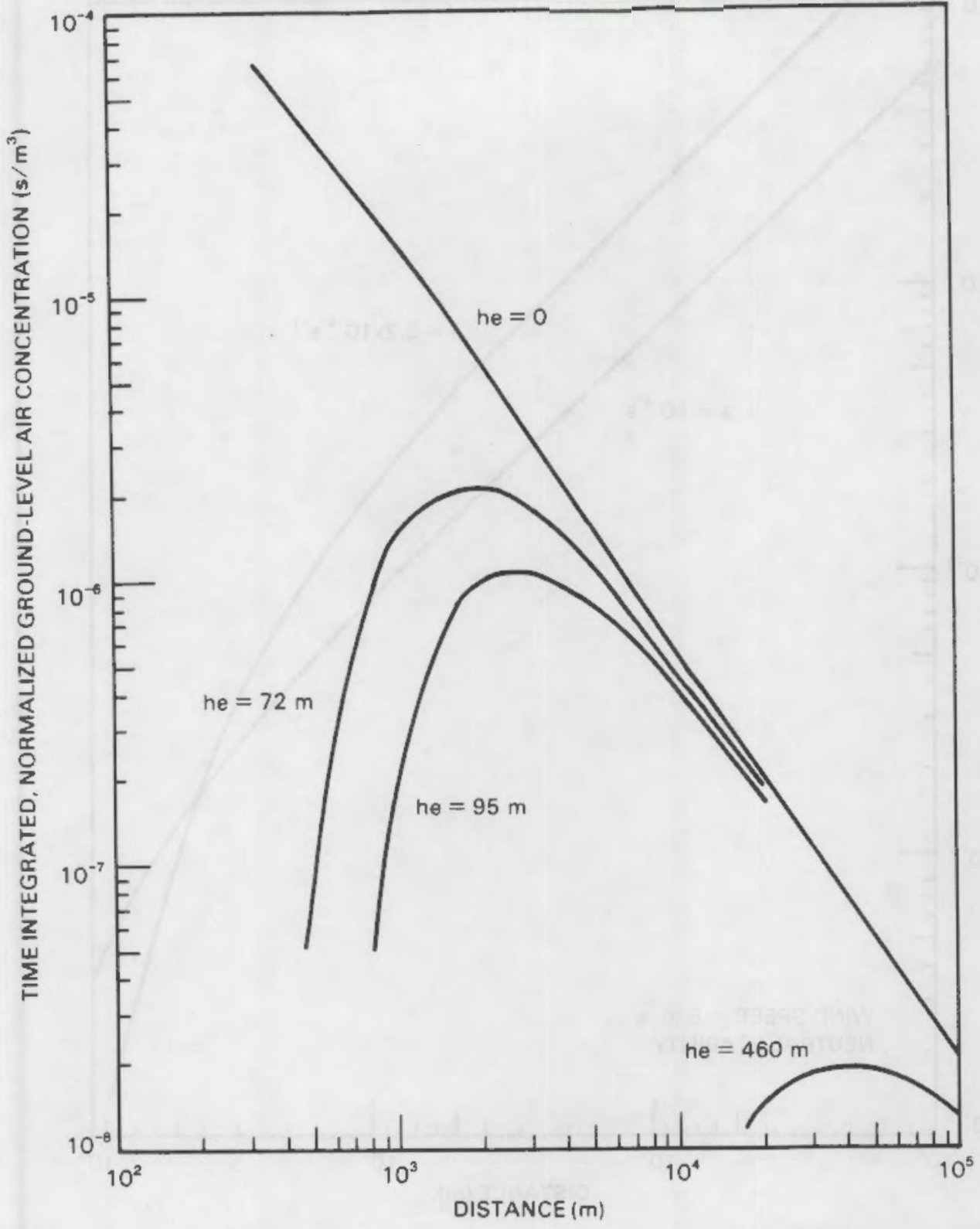

FIGURE 6.8. Estimated Time Integrated, Normalized Ground-Level Air Concentrations for Various Effective Release Height Assumptions for Early Ginna Steam Releases

center of the plume estimated for the Ginna meteorological conditions. The curves were computed for a ground-level release. For elevated releases, the left portions of the curves might be displaced somewhat to account for the time required for the snow to fall from the plume to the ground.

The assumption that the moisture in the plume does not enhance washout is probably not good in the case of Ginna. Figure 6.7 indicates that the Ginna 


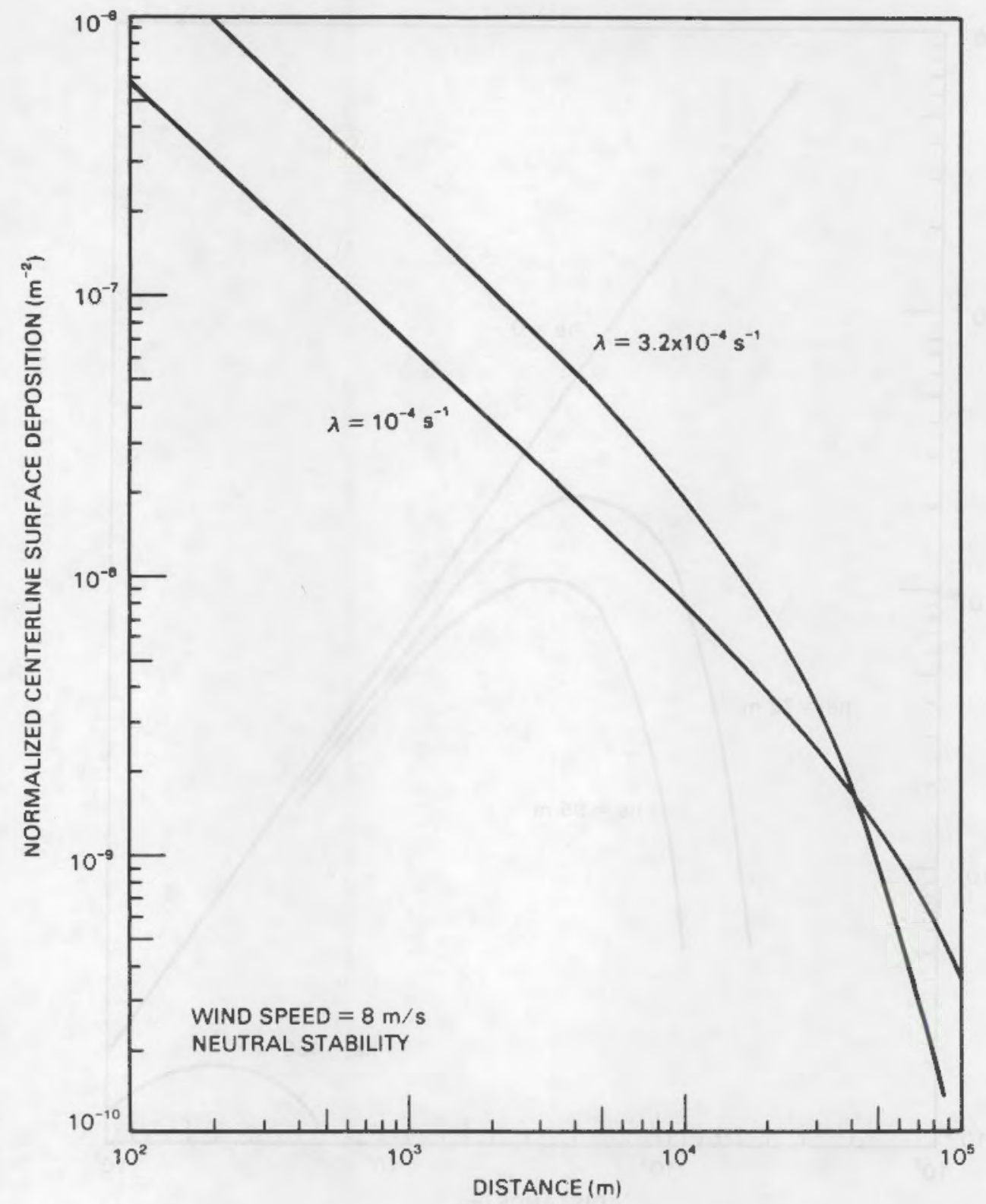

FIGURE 6.9. Normalized Surface Deposition Under a Plume Center Line

plume probably contained a large water excess well downwind of the release point. This excess would condense and fall out of the plume near the release point. As a result, the surface deposition near the source would probably be higher than indicated by Figure 6.9 , and the distant surface concentrations would probably be lower.

Late Saturated Water Releases. During the course of the actions taken to mitigate the consequences of the steam generator tube rupture, the indin steain line from the $B$ steam generator filled with water. As a result, water rather 
than steam was vented through the safety valve during the last opening of the valve, and possibly during the last three openings. When the valve failed to seat correctly after the fifth opening, water continued to leak through the valve at an estimated rate of about $4.5 \mathrm{~kg} / \mathrm{s}$. Isenthalpic expansions of the water to atmospheric pressure gives a liquid/vapor mixture at $100^{\circ} \mathrm{C}$ that is $37 \%$ vapor by mass, but $99.9 \%$ vapor by volume.

The volumetric flow of water/vapor mixture was about $1.4 \mathrm{~m}^{3} / \mathrm{s}$ through each vent. The approximate vertical velocity of the mixture was $14.2 \mathrm{~m} / \mathrm{s}$. The flow values give volume, momentum and buoyancy flux parameters of $0.447 \mathrm{~m} / \mathrm{s}$, $6.35 \mathrm{~m}^{4} / \mathrm{s}^{2}$ and $1.29 \mathrm{~m}^{4} / \mathrm{s}^{3}$, respectively. The plume rise estimates corresponding to these values are small compared with the height of the wake of the reactor building complex. For diffusion purposes, the plume should be considered to be from a ground level source with an appropriate building wake correction.

Much of the contamination released through the safety valve may have been associated with the fraction of the effluent released as liquid water. Assuming that the liquid water leaves the vents as droplets that reach a terminal velocity of $3 \mathrm{~m} / \mathrm{s}$, it is estimated that the droplets will reach the ground about $100 \mathrm{~m}$ downwind of the vents. In reality, the liquid leaving the vents and not evaporating will be distributed around this estimate. However, the point to be made is that the liquid will fall near the source. 



\subsection{REGULATORY GUIDANCE}

Several types of potential accidents at boiling and pressurized water reactors have been identified that have the capacity to result in plumes that could be buoyant. These are three basic scenarios. The first two scenarios are the result of broken steam and hot water lines that vent into the reactor building, steam tunnel, or turbine building. If the volume of steam released is of sufficient magnitude in relation to the volume of the structure where the break occurs, the steam or flashing water will result in over-pressurization of the building and direct venting of the release to the atmosphere. This is likely to result in an initially horizontal plume. If the over-pressurization does not result in a release through the building sides, the effluent will be vented to the atmosphere via the normal building ventilation system. The characteristics of the effluent leaving the building vents will be a combination of those of the effluent from the break and of the atmosphere within the building where the break occurs. The third scenario is a release of a buoyant plume from the atmospheric dump and safety relief valves following a steam generator tube rupture at a pressurized water reactor. In this case, the effluent goes directly to the atmosphere, undiluted, and is released as a highly buoyant, high velocity vertical jet.

\subsection{BOILING WATER REACTORS}

One of the primary concerns at a boiling water reactor is a break in the main steam line. Should this occur, the sudden increase in pressure within the portion of the building complex where the break occurs will result in the operation of blowout panels or rupture of the side of the building. As a result the hot, moist effluent from the break will be released directly to the atmosphere. It is likely that the effluent will leave the building as a horizontal jet of steam carrying with it droplets formed by condensation on particulates from the main steam line and the entrained air. The actual height of the release depends on specific power plant design features and the location of the break. It may be near ground-level, or it may be well above ground-level.

The current approach to estimating the consequences of a main steam line break is to assume that the break occurs during a period when there is an inversion that restricts the vertical diffusion of the effluent to the lower 30 meters of the atmosphere (USNRC 1971). To maximize the ground-level air concentrations, the plume is assumed not to be depleted through either wet or dry deposition. In addition, $F$ stability and a $1 \mathrm{~m} / \mathrm{s}$ wind in the lower layer of the atmosphere may be assumed to estimate the maximum likely air concentration. These assumptions are reasonable for routine licensing applications in estimating the consequences of maximum breaks under worst case conditions.

Regulatory Guide 1.5 does not attempt to treat the consequences of smaller breaks in the main steam line or breaks in other steam or hot water lines. In general, however, the approach outlined in the Regulatory Guide can be used for breaks in any of the lines that would activate blowout panels or rupture the sides of structures. Assuming that the break in a steam or water line results 
sides of structures. Assuming that the break in a steam or water 1 ine results in steam at $100^{\circ} \mathrm{C}$, and that the blowout panel operation or building rupture takes place at a 0.25 psi over-pressure, lines that could lead to direct releases to the atmosphere through the building sides can be identified by comparing the mass of steam that would result from a break in the line to the mass of steam required to reach a 0.25 psi over-pressure. The mass of steamm required to reach a 0.25 psi over-pressure is approximately $0.01 \mathrm{~kg} / \mathrm{m}^{3}$ of building volume.

If the mass of steam released following a break in a steam or hot water line is not sufficient to breach the building, the likely exit for the effluent from the break is the building's heating and ventilation system vents. Between the break and the vents, the effluent will mix with building air. As a result, a significant portion of the potential buoyancy of the effluent will be lost prior to release to the atmosphere. Releases through the heating and ventilation system vents should be treated as though they were non-buoyant, using an elevated or ground-level plume diffusion model as appropriate. (See Ramsdell 1983 for a discussion of non-buoyant vent releases.)

The approach to evaluation of the potential consequences steam line breaks outlined in Regulatory Guide 1.5 is specifically intended for routine licensing applications. However, its use in the event of an actual accident is likely to lead to overestimates of the ground-level air concentrations. The overestimates are likely for two reasons. First, the restriction of the pluine to the lowest $30 \mathrm{~m}$ of the atmosphere is unrealistic except in the most restrictive conditions, and second, because of its buoyancy, the plume from a steam line break that is large enough to breach the structure is likely to rise somewhat even though it exits the building horizontally.

As an alternative to the Regulatory Guide 1.5 approach, it is suggested that a ground-level source Guassian plume model, with reflection at the top of the mixing layer by used, along with current meterological conditions, in the event of an actual accident. Assuming a ground-level release will lead to a conservative estimate of the air concentrations, while the relaxation of the limitation on vertical diffusion will make the concentration estimates more realistic.

The release duration assumed in the Regulatory Guide is 30 minutes. Judging from the durations estimated in the earlier sections of this report, the duration assumed in the Guide is excessive. Breaks in the main steam lines of boiling water reactors will result in rapid closure of the main steam isolation valves. Once the isolation valves close, the rate at which steam leaves the break will decrease quickly as the pressure in the line drops. It would be realistic to assume two phase release following a steam line break. In the first phase of the release the flow would be high. This phase might be assumed to continue for a one to five minute period. The second phase would correspond to continued evaporation of any residual hot water that collected on the floor of the building in which the break occurred. This phase could be assumed to last significantly longer than the first phase, perhaps it could last an hour or more. 
Atmospheric stability, mixing layer thickness and wind speed will affect the air concentrations and deposition of effluents released by steam line breaks as they would the concentrations and deposition of other effluents. However, the ambient temperature and humidity assume a more important role than normal because they are closely related to the formation and growth of droplets

in the plume. Material released during cold weather is likely to deposit nearer the source due to condensation within the plume than would be the case during warm weather.

\subsection{PRESSURIZED WATER REACTORS}

To the extent that releases from pressurized water reactors occur as a result of breaks in steam and hot water lines, Regulatory Guide 1.5 and the discussion above may be applied to evaluation of the consequences of the releases. However, it would be inappropriate to apply the criteria in Regulatory Guide 1.5 or the above discussion to the releases from atmospheric dump and safety relief valves that would be expected to follow a steam generator tube rupture. Releases through these valves and their associated vents occur in high temperature, high velocity jets (assuming correct operation of the valves). These releases should be treated as elevated plumes under normal circumstances.

Following a steam generator tube rupture, an intentional or inadvertant release may occur through an atmospheric dump or safety relief valve. Should this occur, it is one of the few circumstances in which the release condition are well known. The valve and its associated vents will act as a throttle to limit the flow from the steam line to the atmosphere. When the valve opens, the flow through it will be approximately equal to the rated flow, and the flow can be assumed to be approximately constant until the pressure in the steam line drops to the point where the valve reseats. If the conditions (pressure and temperature) in the steam line are known, the conditions just beyond the vent exit can be estimated by assuming isenthalpic expansion of the steam to atmospheric pressure and temperature.

To estimate the potential consequences of a steam generator tube rupture during a routine licensing evaluation, it would seem appropriate to assume that a safety relief valve is opened and that contaminated steam flows through the valve for a period of time, perhaps 15 minutes. When the valve is opened, the flow through the valve should be assumed to be equal to the valve's rated flow.

By analogy with Regulatory Guide 1.5 , it would be appropriate to assume that the release takes place during stable atmospheric conditions. However, because the release is a vertical jet that has a good deal of vertical momentum as well as being highly buoyant, it is appropriate to assume an elevated plume rather than assuming a ground-level release. It is conservative to assume a moderate wind speed in addition to stable atmospheric conditions when estimating plume rise. Therefore, the atmospheric conditions assumed as a worst case should be approximately $F$ stability and a $4 \mathrm{~m} / \mathrm{s}$ wind speed. With these assumptions the ground-level air concentration can be estimated using the standard elevated source Guassian plume diffusion model. If additional 
conservatism is desired, the top of the mixing layer may be assumed to be a reflecting boundary that coincides with the effective release height.

In the event of an actual steam generator tube rupture, the potential consequences of a release through a dump or safety valve may be assessed using the elevated source Guassian plume diffusion model. However, in this circumstance the actual meterological conditions should be used to determine the top of the mixing layer, plume rise and the diffusion coefficients. The actual meteorological conditions should also be used to evaluate the likelihood of surface contamination near the release point.

Occasionally safety valves do not reseat properly when the pressure drops to the reset point. The consequences of a leaking atmospheric dump or safety valve should be considered in both routine licensing and actual accident evaluations. This may be done by assuming a flow through the valve that is a small fraction of the rated flow. The leak rate following the last opening of the safety valve after the Ginna steam tube rupture was about $5 \%$ of the rated flow. Literature related to leak rates through valves that fail to reseat should be examined to determine a typical leak rate for this application. Until a better rate is determined, a rate in the range of 5 to 10 percent of the rated flow should provide a "feel" for the consequences of a valve leak. 


\subsection{REFERENCES}

American National Standards Institute. 1981. "Time Response Design Criteria for Safety Related Operator Actions." ANSI Standard N660.

Arizona Public Service Company. 1980. "Palo Verde Final Safety Analysis Report." Docket Numbers 50-528 through 50-530, Nuclear Regulatory Commission, Washington, D.C.

Briggs, G. A. 1969. Plume Rise. USAEC Critical Review Series, TID-25075.

Briggs, G. A. 1974. "Plume Rise from Multiple Sources." In Cooling Tower Environment--1974. ERDA Symposium Series, College Park, Maryland. March 4-6, 1974, CONF-740302, pp. 161-179.

Briggs, G. A. 1975. "Plume Rise Predictions." In Lectures on Air Pollution and Environmental Impact Analyses. Workshop Proceedings, American Meteorological Society, Boston.

Commonwealth Edison Company. 1978. "Byron/Braidwood Stations Final Safety Analysis Report." Docket Numbers 50-454 through 50-457, Nuclear Regulatory Comrnission, Washington, D.C.

Combustion Engineering Inc. 1979. "Combustion Engineering Standardized Safety Analysis Report Final Safety Analysis Report." Docket Number 50-470, Nuclear Regulatory Commission, Washington, D.C.

Consumers Power Company. 1977. Midland Plant 1 \& 2 Final Safety Analysis Report," Docket Numbers 50-329 and 50-330, Nuclear Regulatory Commission, Washington, D.C.

Fohl, T. 1967. "Optimization of Flow for Forcing Stack Wastes to High Altitudes." J.Air Pollut, Control Assoc. 17:730-733.

Gifford, F. A. 1968. "An Outline of Theories of Diffusion in the Lower Layers of the Atmosphere." In Meteorology and Atomic Energy - 1968. TID-24190, U.S. Atomic Energy Commission, pp. 65-116.

Gifford, F. A. 1975. "Atmospheric Dispersion Models for Environmental Pollution Applications." In Lectures on Air Pollution and Environmental Impact Analyses. American Meteorological Society, Boston Massachusetts.

Hanna, S. R. 1974. "Meteorological Effects of the Mechanical Draft Cooling Towers of the Oak Ridge Gaseous Diffusion Plant." In Cooling Tower Environment--1974. ERDA Symposium Series, College Park, Maryland. March 4-6, 1974, CONF-740302, pp. 291-306.

Hanna, S. R., G. A. Briggs, and R. P. Hosker. 1982. Handbook on Atmospheric Diffusion. DOE/TIC-11223. U.S. Department of Energy, P. 108. 
Hosker, R. P., Jr. 1981. Methods for Estimating Wake Flow and Effluent Dispersion Near Simple Block-Like Buildings. NOAA Technical Memorandum ERL ARL-108, Atmospheric Turbulence and Diffusion Laboratory, Oak Ridge, Tennessee, p. 156.

Mississippi Power \& Light Company. 1978. "Grand Gulf Final Safety Analysis Report." Docket Numbers 50-416 and 50-417, Nuclear Regulatory Commission, Washington, D.C.

Nickola, P. W. 1971. "Measurements of the Movement, Concentration and Dimensions of Clouds Resulting from Instantaneous Point Sources." J. Appl. Meteor., 10:962-973

Pennsylvania Power \& Light Company. 1978. "Susquehanna Final Safety Analysis Report." Docket Numbers 50-387 and 50-388, Nuclear Regulatory Commission, Washington, D.C.

Portland General Electric. 1973. "Trojan Nuclear Plant Final Safety Analysis Report." Docket Number 50-344, Nuclear Regulatory Commission, Washington, D.C.

Ramsdel1, J. V. 1971. "The Real Plume and Its Relationship to the Apparent Plume." In Pacific Northwest Laboratory Annual Report for 1970 to the USAEC Division of Biology and Medicine Volume II: Physical Sciences Part 1. Atmospheric Sciences, BNWL-1551 Vol. II Part 1, Pacific Northwest Laboratory, Richland, Washington.

Ramsde11, J. V. 1983. Evaluation of the Split-H Approach to Modeling Nonbuoyant Releases from Vent Stacks. NUREG/CR-3016 (PNL-4516). U.S. Nuclear Regulatory Commission, Washington, D.C.

Slade, D. H., ed. 1968. Meteorology and Atomic Energy-1968. U.S. Atomic Energy Commission, TID-24109. Washington, D.C.

Stewart, N. G., H. G. Gale and R. N. Crooks. 1954. "The atmospheric Diffusion of Gases Discharged from the Chimney of the Harwell Pile (BEP0)." Int. J. of Air Poll. 1:87-102.

Tennessee Valley Authority. 1970. "Browns Ferry Final Safety Analysis Report." Docket Numbers 50-259, 50-260, and 50-296. Nuclear Regulatory Commission, Washington, D.C.

Turner, J. S. 1960. "Intermittent Release of Smoke from Chimneys." J. Mech. Sci. 2:97-100.

U.S. Nuclear Regulatory Commission. 1971. Assumptions Used for Evaluating the Potential Radiological Consequences of a Steam Line Break Accident for Boiling Water Reactors. Regulatory Guide 1.5. (Safety Guide 5). Washington, D.C. 
U.S. Nuclear Regulatory Commission. 1977. Methods for Estimating Atmospheric Transport and Dispersion of Gaseous Effluents in Routine Releases from LightWater-Cooled Reactors. Regulatory Guide 1.111, Revision 1, Washington, D.C., p. 24.

U.S. Nuclear Regulatory Commission. 1980. Evaluation of Steam Generator Tube Rupture Events. NUREG-0651. Washington, D.C.

U.S. Nuclear Regulatory Commission. 1982. NRC Report on the January 25, 1982 Steam Generator Tube Rupture at R. E. Ginna Nuclear Power Plant. NUREG-0909. Washington, D.C.

Washington Public Power Supply System. 1981. "WNP 1 \& 4 Final Safety Analysis Report." Richland, Washington. Docket Numbers 50-460 and 50-513, Nuclear Regulatory Comrnission, Washington, D.C. 



\section{DISTRIBUTION}

No. of

Copies

OFFSITE

U.S. Nuclear Regulatory Commission

Division of Technical

Information and Document

Control

$20 \mathrm{Mr}$. J. Fairobent

Division of System Integration

office of Nuclear Reactor

Regulation

U.S. Nuclear Regulatory Commission

Washington, DC 20555
No. of

Copies

ONSITE

50 Pacific Northwest Laboratory

K. J. Allwine

G. F. Athey

D. W. Dragnich

J. C. Doran

J. G. Droppo

D. W. Faletti

C. S. Glantz

R. K. Hadlock

C. G. Lindsey

M. A. McLean

J. V. Ramsdell (31)

W. F. Sandusky

C. D. Whiteman

Publishing Coordination (2)

Technical Information (5) 



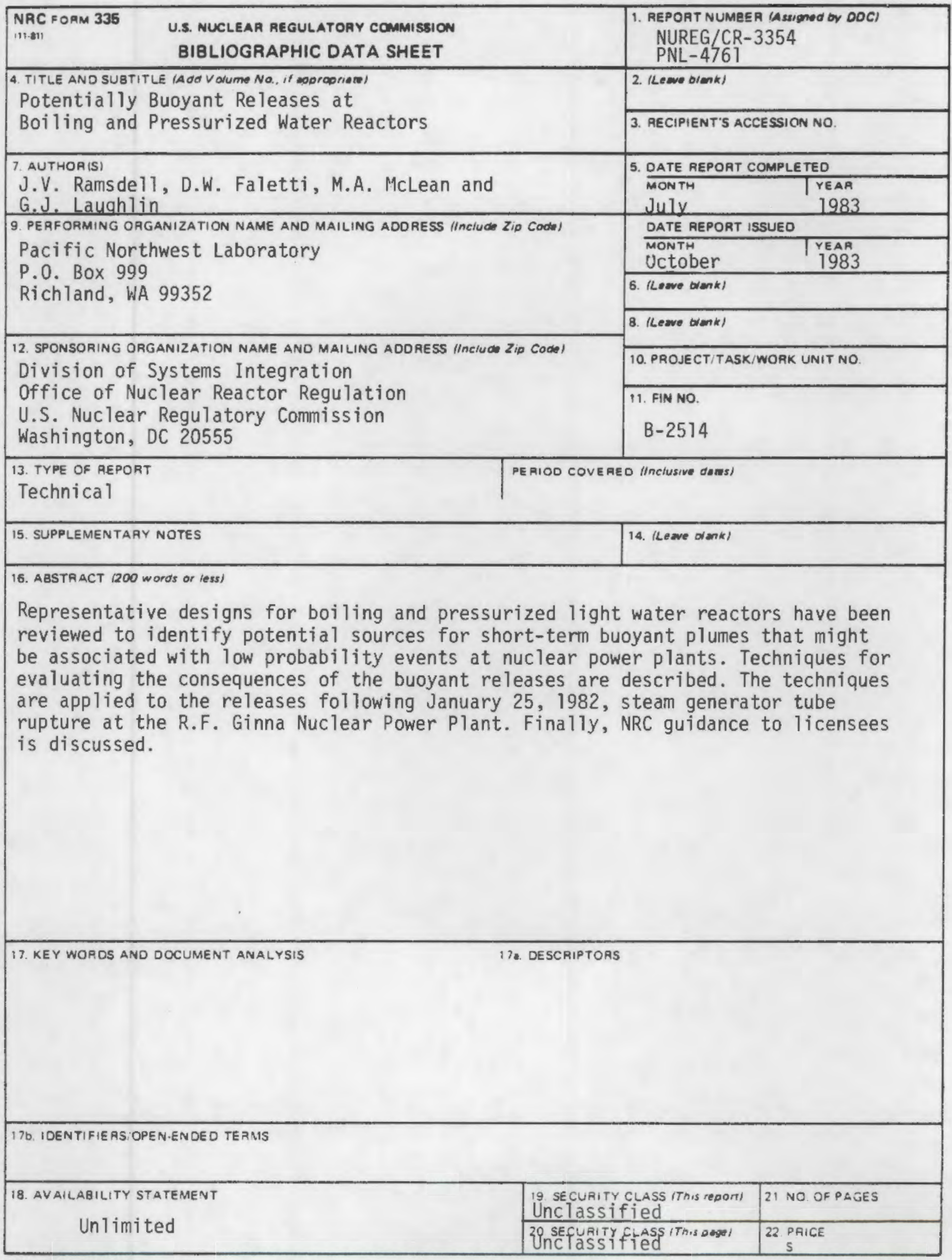

NAC FOAM 335 "11.8\% 
